\title{
Active metabolites of the genus Piper against Aedes aegypti: natural alternative sources for dengue vector control
}

\author{
André M. Marques ${ }^{1 凶}$, Maria Auxiliadora C. Kaplan
}

\begin{abstract}
The mosquito, Aedes aegypti, is the principal vector of the viruses responsible for dengue and dengue hemorrhagic fevers. The mosquito is widespread throughout tropical and sub-tropical regions; its prevalence makes dengue one of the most important mosquito-borne viral diseases in the world occurring annually in more than 100 endemic countries. Because blood is essential to their development cycle, the Aedes species maintains a close association with humans and their dwellings. Fittingly, the most widely adopted strategy to decrease the incidence of these diseases is the control of the mosquito larvae population. The emergence of insecticide-resistant mosquitoes has amplified the interest in finding natural products effective against Aedes aegypti adults, as well as larvae. Plantderived compounds have played an important role in the discovery of new active entities for vector management as they are safer and have lower toxicity to humans in comparison to conventional insecticides. This review assesses a naturally occurring plant matrix and pure compounds of the Piper species, which have been shown to be active against Aedes aegypti.
\end{abstract}

Keywords: dengue; Aedes aegypti; Piper; Piperaceae; larvicidal metabolites; tropical diseases.

Edited by Alberto Acosta四

1. Instituto de Pesquisas de Produtos Naturais (IPPN), Centro de Ciências da Saúde, Bloco H - $1^{\circ}$ andar, Universidade Federal do Rio de Janeiro. CEP 21.941-590 - Rio de Janeiro - RJ, Brasil.

Received: 24-02-2014 Accepted: 24-07-2014

Published on line: $25-08-2014$

Citation: Marques AM, Kaplan MAC (2015) Active metabolites of the genus Piper against Aedes aegypti: natural alternative sources for dengue vector control. Universitas Scientiarum 20(1): 61-82 doi: 10.11144/ Javeriana.SC20-1.amgp

Funding: CAPES; CNPq.

Electronic supplementary material: N/A

\section{Introduction}

Dengue: an emerging disease in the world

Dengue is transmitted to humans by the Aedes aegypti and Aedes albopictus mosquitoes (Ramasamy et al. 2011). Aedes aegypti is the principal mosquito vector of dengue viruses. Humans and their dwellings provide the vector with the blood and stored clean water necessary for its life cycle (Platt et al. 1997). A. aegypti mosquitoes have adapted to the environment and have become highly resilient; this makes their eradication very difficult. $A$. aegypti eggs can survive long latency periods without water and can resist desiccation for several months in the environment. Dengue occurs annually and is endemic in over 100 
countries in tropical and subtropical regions. Large mosquito populations are associated with the rainy season when the conditions are optimal for breeding and larval development (WHO 2009). Dengue epidemics commonly occur when a high number of vector mosquitoes coexist with a large population of humans with no immunity to one of the four virus types (Gould \& Solomon 2008). Only in the 1950s did dengue emerge as a global problem; currently, more than one-third of the world's population lives in dengue transmission risk areas. Limited travel possibilities kept dengue geographically restricted and relatively controlled until the middle of the $20^{\text {th }}$ century; during the $19^{\text {th }}$ century, dengue was a sporadic disease with epidemics that lasted long intervals. After the Second World War, the Aedes mosquitoes were disseminated globally, especially in cargo transport, which is thought to have played a crucial role in the spread of the viruses. It was not until the 1950's that Dengue Hemorrhagic Fever (DHF) was documented during epidemics of the disease in the Philippines and Thailand. Then, in 1981 high numbers of DHF cases began to appear in the Caribbean and Latin America. (Dick et al. 2012). Incidence has increased 30-fold in the last 50 years. The World Health Organization (WHO 2012) estimates that 50-100 million dengue infections occur annually in more than 100 endemic countries. An estimated 2.5 billion people live in areas tropical and subtropical areas where dengue viruses can be transmitted. After malaria, dengue fever is the most widespread tropical disease. In tropical countries, epidemics of dengue result in thousands of hospital admissions, human suffering and massive economic losses; early recognition and prompt treatment can lower the risk of developing this severe disease (Epelboin et al. 2013).

Although the need for dengue vaccines was recognized in the 1940s, pharmaceutical companies were unresponsive because of the limited potential markets. This continued throughout much of the $20^{\text {th }}$ century. However, in 2012, outbreaks were reported in several continents of the world making dengue the most relevant mosquito borne viral disease in the world; the disease has become an imminent threat to the health and economy of most tropical populations (Murray et al. 2013). The emergence and spread of all four serotypes of the dengue virus throughout the tropical regions of the world represents the threat of a global pandemic with alarming risks and losses for both human health and the economy (WHO 2012). The search for new vaccines still continues today, and the development of dengue vaccines has increased dramatically. Currently, there is no effective vaccine to prevent the dengue virus serotypes; as a result, the best way to prevent dengue fever is to eliminate the dengue vector and the multiplication focus of the larvae. Research into the development of dengue vaccines has produced various candidates in phase II and I clinical trials. In 2012, Sanofi-Pasteur developed the only vaccine candidate in phase III clinical trials (Simmons et al. 2012); however, because of some particularities of the virus, the search for an effective dengue vaccine is still a challenge. The exposure to just one serotype will cause only minor illness, but the subsequent exposure to a second dengue serotype will increase the probability of the illness progressing to the severe and sometimes fatal dengue hemorrhagic fever. Therefore, the focus is to produce a tetravalent vaccine that provides long-term protection against all virus serotypes (Thisyakorn \& Thisyakorn 2013); an effective vaccine should be equally potent against all four serotypes as a deficient vaccine may place the individual at risk for the illness to become severe. Mainly the focus of research has been finding a combination of specific vaccines for each serotype; recently, Sanofi Pasteur researchers proposed a vaccine following this combination. Early testing of this vaccine in humans has shown an equal immune response to all four serotypes. More than 4000 children were vaccinated in Thailand; the results showed that the vaccine was effective in preventing illness caused by three serotypes. The vaccine was effective $55.6 \%$ for serotype $1,75.3 \%$ for serotype 3 , and $100 \%$ for serotype 4 . The vaccine, however, showed no effect against dengue serotype 2 . This serotype is the most prevalent and chiefly responsible for outbreaks of severe illness worldwide (Guy et al. 2010). The results of the first trial of the effectiveness of a possible vaccine for dengue have engendered both enthusiasm and disappointment. Controlling the mosquitoes that transmit dengue is necessary but not sufficient to combat the disease. The discovery of a safe and effective vaccine to prevent the global dengue epidemics is long overdue. 
Dengue in Brazil: the endemic country with the highest dengue presence in the world

Dengue has emerged as one of the major public health problems in Brazil, in the last years. Approximately 2.5 million cases of the disease and 280.000 hospitalizations were recorded between 2007 and 2010 (Brazilian Health Ministry 2012). Despite the significant investments and the efforts by health and disease prevention authorities, the incidence of dengue is still high, and the methods of control are limited. Serotypes 1, 2, 3 viruses are prevalent in all regions of Brazil; however, in the second half of 2010, the dissemination of DENV4 has been evident from the northern region to the northeast and southeast regions (WHO 2012).

Cycles of high dengue transmission dengue are characteristic in Brazil; significant outbreaks were reported in 1998 (DENV1), 2002 (DENV3), 2008 (DENV2) and 2010 (DENV1). The highest number of outbreaks occurred in 2002, 2008 and 2010
(Pan American Health Organization 2010); in 2011, 764.032 cases of dengue reported in Brazil and 591.384 in 2012 (Brazilian Health Ministry 2012.). Since November $15^{\text {th }}, 2013$, more than 385.354 cases have been confirmed and reported to the WHO in Brazil (Figure 1). A total of 4.332 .731 cases of dengue were reported from 2001 to 2007 in all the Americas; $64.6 \%$ of these cases were reported in Brazil, Argentina, Paraguay and Uruguay, 6733 of these were DHF and 500 fatal. Of these cases, 98.5\% were reported in Brazil where serotypes (DEN-1, DEN-2, DEN-3, DEN-4) circulate making it the country with the highest number of fatal cases in this region (PAHO 2008). Reports of dengue in Brazil have occurred since $19^{\text {th }}$ century; however, epidemics have occurred more frequently in the country, in the last decades. In 2008 alone, between January and April, more than 158.000 dengue cases, thousands of hospital admissions and hundreds of deaths were reported in Rio de Janeiro. The military was called upon to aid in the massive response to improve the healthcare and vector control operations in Rio de Janeiro

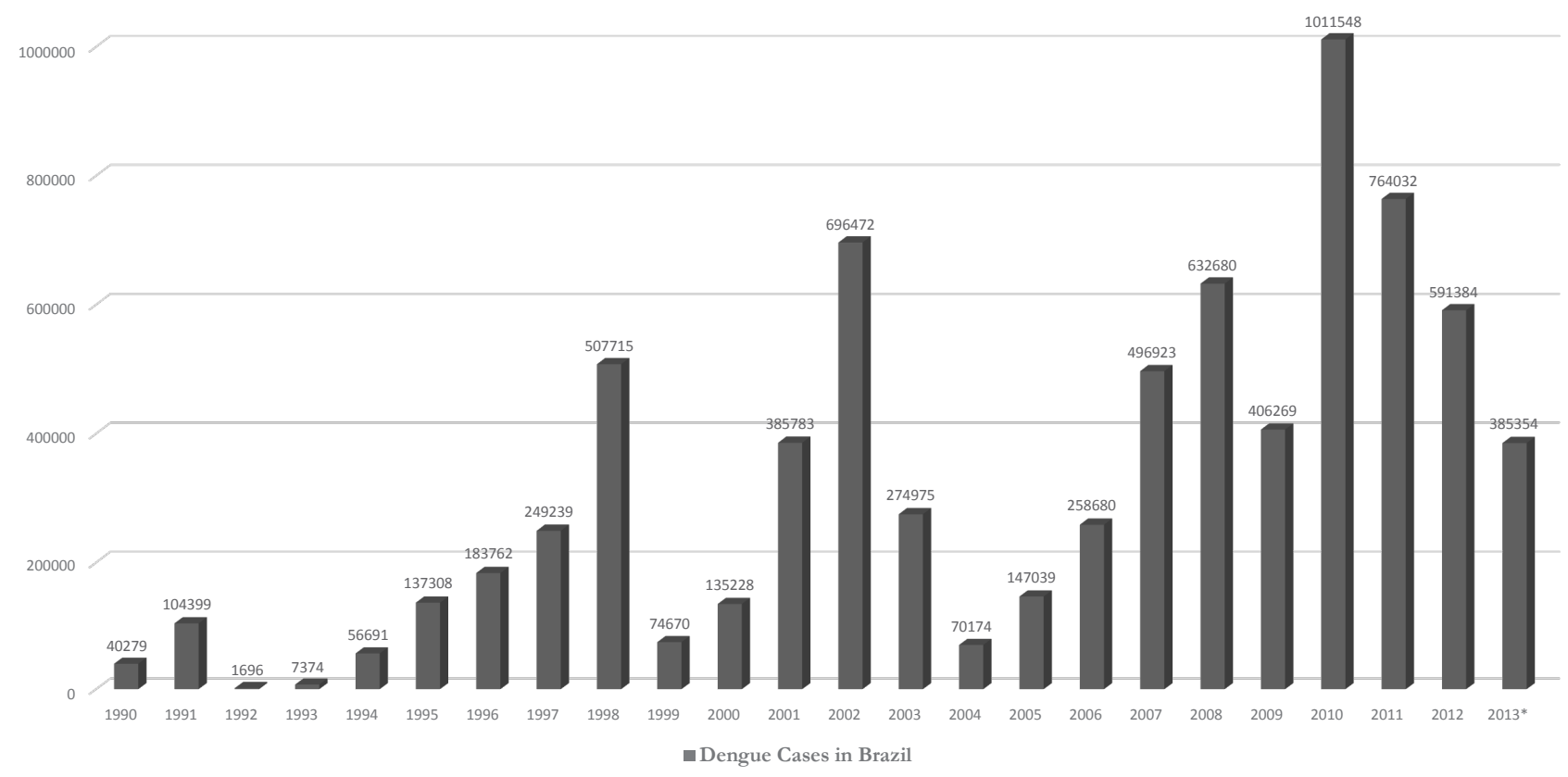

Fig. 1. Dengue cases reported by the Brazilian Health Ministry between 1990 and 2013* (Until November 15 ${ }^{\text {th }} 2013$ ). 
(WHO 2012). Figure 2 shows the fatal cases of DHF reported by the Brazilian Health Ministry between 1990 and 2012. At least 2.000 DHF related deaths have been reported in Brazil, in the last two decades;
Bolivia (16207), El Salvador (15207), Colombia (53303) and Peru (9917). Argentina has the lowest average with only 4501 dengue cases reported (WHO 2012) (Figure 3).

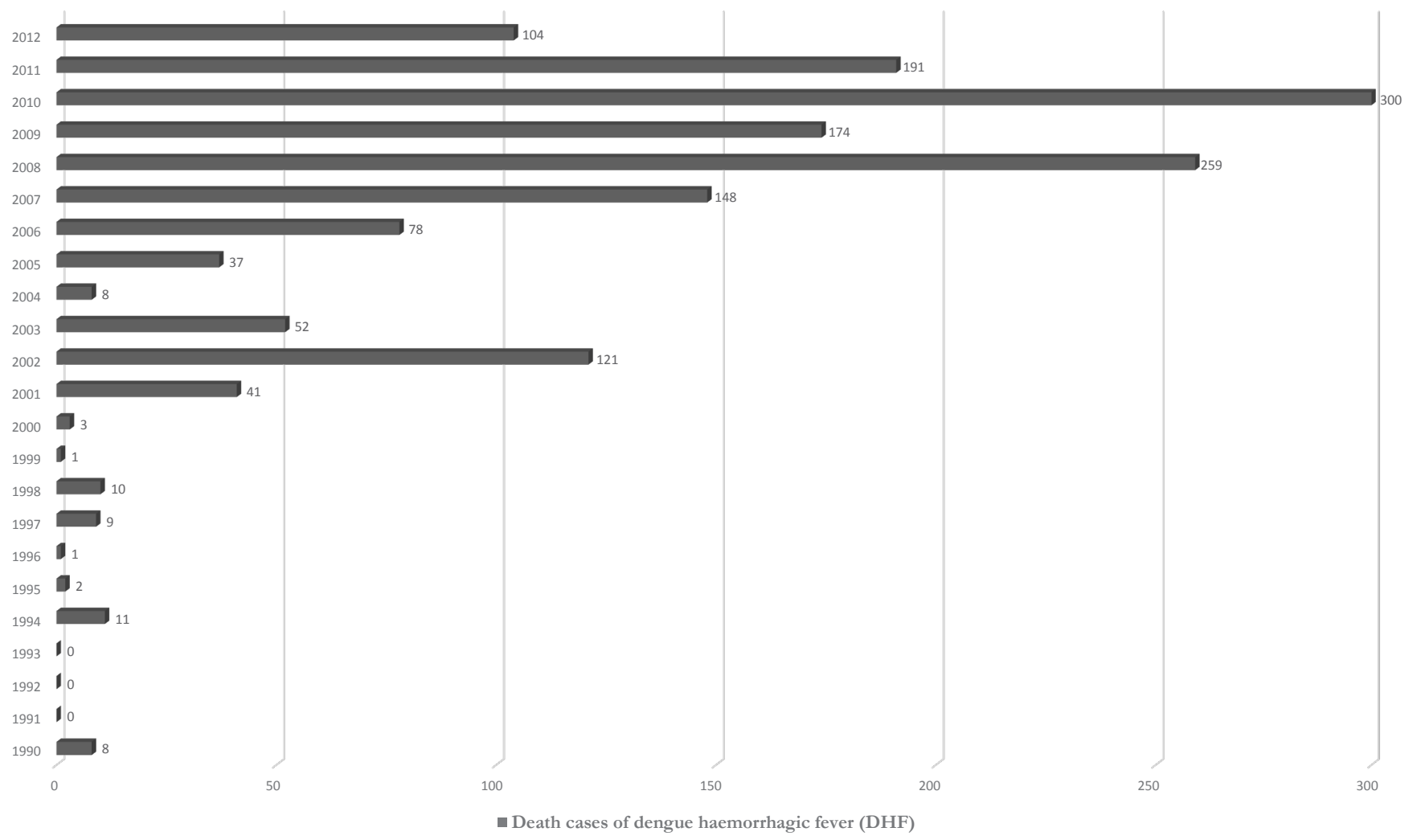

Fig. 2. DHF death cases reported by the Brazilian Health Ministry between 1990 and 2012.

more than 1470 deaths were confirmed from 20022012 alone. Overall, 5.350 .176 cases of dengue were reported in Brazil, an average of 486.379,6 cases/year. Despite control efforts, more than one million cases of dengue were reported in Brazil in 2010; this reflects a deteriorating global situation in Brazil (Brazilian Health Ministry 2012). Fittingly, dengue has become a pressing issue within the current health system. From 2004-2010, more than half of the number of reported dengue cases in Latin America was issued by Brazil with an average number of cases of 447.446. For this same period, the ten most endemic countries in Latin America, after Brazil, are Honduras (25972), Costa Rica (18967), Mexico (75353), Venezuela (61612),
Natural Compounds as a potential alternative in the discovery of new active pesticides

Naturally occurring metabolites have a wide range of biological actions. Their chemical and biological diversity are the consequences of a long coevolutionary process involving a vast number of species in the environment (Duke et al. 2010). This biological potential is used in signing processes, mostly to protect the plant from a pathogen, herbivore, or competitor. Many plant products have insect repellents properties. These secondary metabolites act to influence the insect feeding behavior, growth and development cycle in order to protect the plant or in some cases to attract 


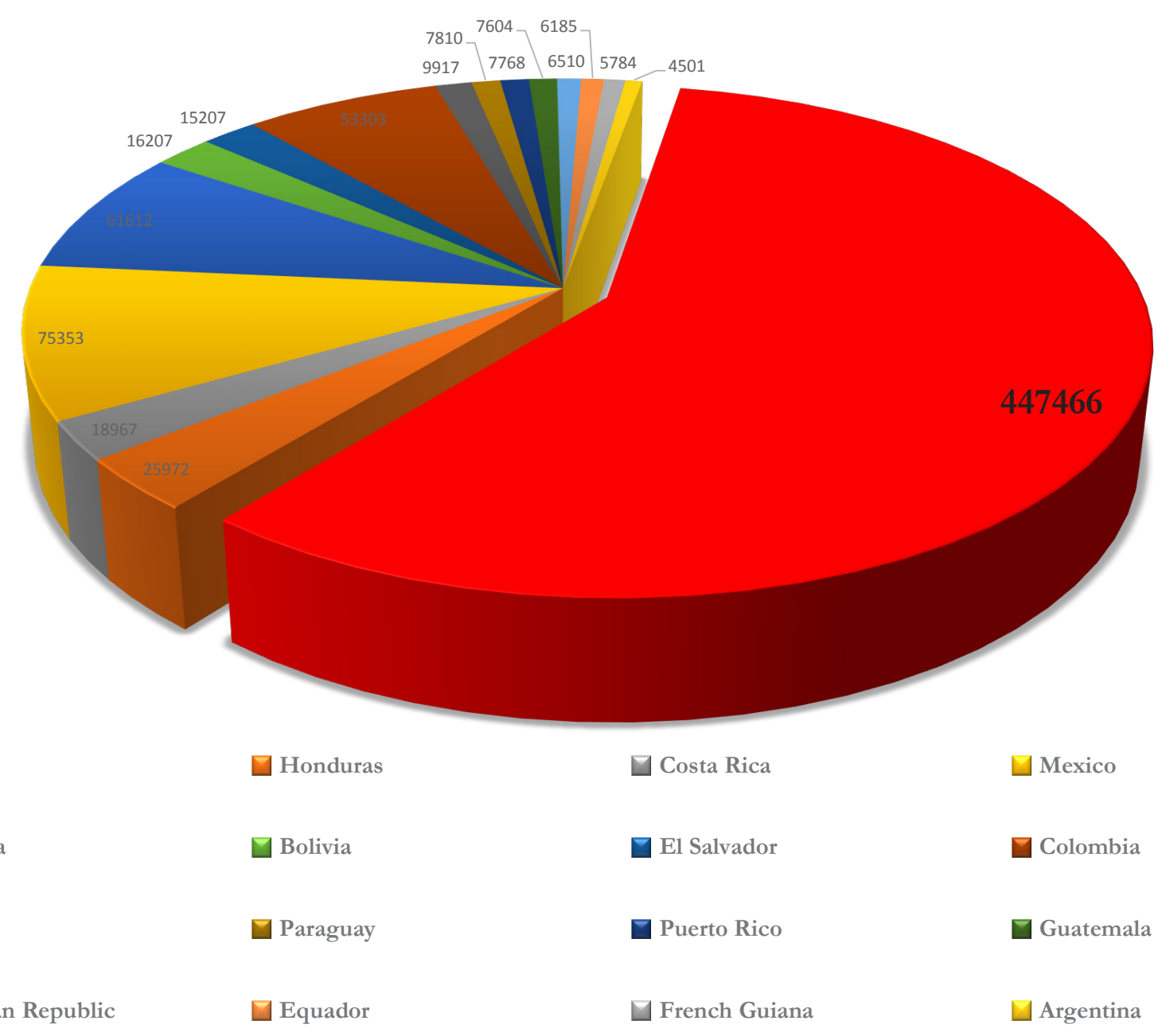

Fig. 3. Dengue average cases number reported cases in Latin America from 2004-2010.

pollinators as well (Heil \& Bostock 2002). Many insect repellents are volatile compounds and can act as attractants in the pollination process. For example, geraniol, a common monoterpene in citric aromatic plants repels certain undesirable insects like houseflies but attracts insects like honeybees; geraniol is also produced by the scent gland of these bees (Duke 1990).

Although consumers show great interest in natural pesticides, they are not as interesting to industry. The synthesis of these natural components entails an increased financial burden because of their complex structures, sometimes, of multiple stereocenters. Additionally, altering their structure can often change the efficacy of synthetic pesticides and intellectual property on these pesticides is difficult to defend and is easily obtained for altered compounds (Duke et al. 2010). There is a growing need to use environmentally friendly chemicals for pest management, but new active pesticide candidates should be efficient, and selectively toxic, highly toxic toward their intended targets and subtle toward non-target organisms, especially humans (Das 2013). Most pesticides are synthetic compounds. Some of them use natural toxins and a few synthetic versions of natural toxins. Due to the growing interest in safer and natural insecticides, there has been a significant rise in unmodified natural compounds. The acceptance of such products drive 
research toward finding even better unmodified natural product insecticides (Dayan et al. 2009). Despite not being embraced by industry because of their natural compounds, from 1997 to 2010, 69.3\% of all the registrations (277) made before the Environmental Protection Agency were of conventional and biopesticides. Five groups of insecticides, carbamates, neonicotinoids, pyrethroids, organophosphates, and natural products accounted for over three-quarters of worldwide sales. Three of these, the neonicotinoids, pyrethroids, and natural products are either entirely natural product based (unmodified) or derived from natural products. Combined worldwide sales percentage was 42.8\%; pyrethroids accounted for $19.5 \%$, neonicotinoids $15.7 \%$, and natural products 7.6\% (Cantrell et al. 2012).

The emergence of insecticide-resistant mosquitoes has bolstered the interest in finding new effective products against adult Aedes aegypti mosquitoes as well its larvae. The control of this insect pest remains an important issue in agriculture and medicine (Bisset et al. 2013, Vontas et al. 2012, Lima et al. 2011). Chemicals continue to lose their efficiency against A. aegypti compelling the use of larger quantities or different kinds of pesticides to eliminate the mosquito vector. Because no vaccine has been effective in preventing dengue, the best control measure to prevent infection is to eliminate adult mosquitoes, and their larvae. Many strategies have been used to control A. aegypti mosquitoes and larvae such as the use of bioenseticida Bacillus thuringiensis H-14 (Bti), Gambusia and Poecilia afinis spp larvae-eating fish and chemical types of insecticides like pyrethroids, carbamates and organophosphates, as well as the improvement of basic sanitation (Garcez et al. 2013). However, the indiscriminate use of synthetic insecticides has lead to the emergence of resistant strains of mosquitoes and prompted an uncontrolled increase in the mosquito population. This has also caused other undesirable effects, such as environmental pollution and toxicity to humans and other non-target organisms. As a result, finding new environmentally safe alternatives that are potentially more effective and suitable to use in programs to combat $A$. aegypti larvae is imperative. To this end, the current trend is the exploration of natural products of plant origin with larvicidal properties. Recent studies indicate that over 500 insect and mite species are currently resistant to pesticides (Mann \& Kaufman 2012). Plants have been the traditional source of natural pesticides as plants have adapted to increase their survival and reproduction by reducing the impact of herbivores. This work provides an overview of the use of the biologically active compounds found in the Piper species as an alternative against Aedes aegypti to control the dengue virus.

Larvicidal properties of crude extracts and sub-fractions of Piper species

With approximately 2000 species of shrubs, vines, small trees and herbaceous plants the Piperaceae family is widely distributed in tropical and sub-tropical regions throughout the world (Guimarães \& Silvam 2009). The former genera Ottonia and Pothomorphe are now recognized as members of the genus Piper and are the most represented member of the Piperaceae family with approximately 1400 species. Several studies related to the phytochemistry of the Piper species have shown some bioactive metabolites including alkaloids, chromenes, amides, flavonoids and terpenoids. Many of these metabolites have economical and medicinal value (Lara Junior et al. 2012, Marques et al. 2010, 2013, Moraes et al. 2011, Parmar et al. 1997, Raimundo et al. 2009, Rebelo et al. 2012, Silva et al. 2010).

There are an estimated 700 species of the Piperaceae family in Brazil, 265 are related to genus Piper (Guimarães \& Moneteiro 2006). Approximately 592 substances were isolated from the genus Piper in the chemical study published by Parmar et al. (1997). However, it is estimated that until 2000, worldwide, only $10 \%$ of all the Piper species had undergone phytochemical analysis (Myers et al. 2000). Ethnic groups in regions of northern Brazil (Amazon region) and South East Asia have traditionally used several species from this genus in medicine and religious activities (Chaveerach et al. 2006, Cunico et al. 2005). In recent years, the genus Piper has received considerable attention because of its chemical diversity and biologic properties. Biologically active compounds, such as amides, have been studied in the fruit of Piper plants; amides have been used as food-flavoring agents and have potent insecticidal properties (Ahmad et al. 2012). The insecticidal properties of several species of this genus have also been examined (Cunico et al. 2005). Piper nigrum and Piper guineense are used as insecticides 
and molluscicides in different parts of Africa, while in India species like Piper longum, Piper betle and Piper cubeba have shown insecticidal activity against mosquitoes and flies (Lee 2005). In the Amazon region, ethnobotanical sources indicate that Piper aduncum, P. amapaense, $P$. baccans, $P$. capitarianum, $P$. cyrtopodum, $P$. dilatatum, $P$. erectipillum, $P$. hostmannianum, $P$. tuberculatum and $P$. peltata are traditionally used by indigenous people to prevent many conditions (Pohlit et al. 2004). The most recognized insecticidal compounds from the Piper species were isolated from $P$. nigrum, $P$. guineense and $P$. tuberculatum; their biological activities were studied in relation to a variety of insects with different mode actions, which include contact toxicity, synergism, repellent, and antifeedant properties (Scott et al. 2008). It is ethnobotanical studies that have guided the pursuit for insecticide active metabolites from the genus Piper. The traditional use of these active metabolites tends to stimulate phytochemical investigation; their longestablished use frequently indicates the effectiveness of these natural compounds against parasites.

The search for new, natural insecticidal metabolites can be achieved by chromatographically separating them from complex natural matrixes. The effectiveness of phytocompounds against mosquito larvae can

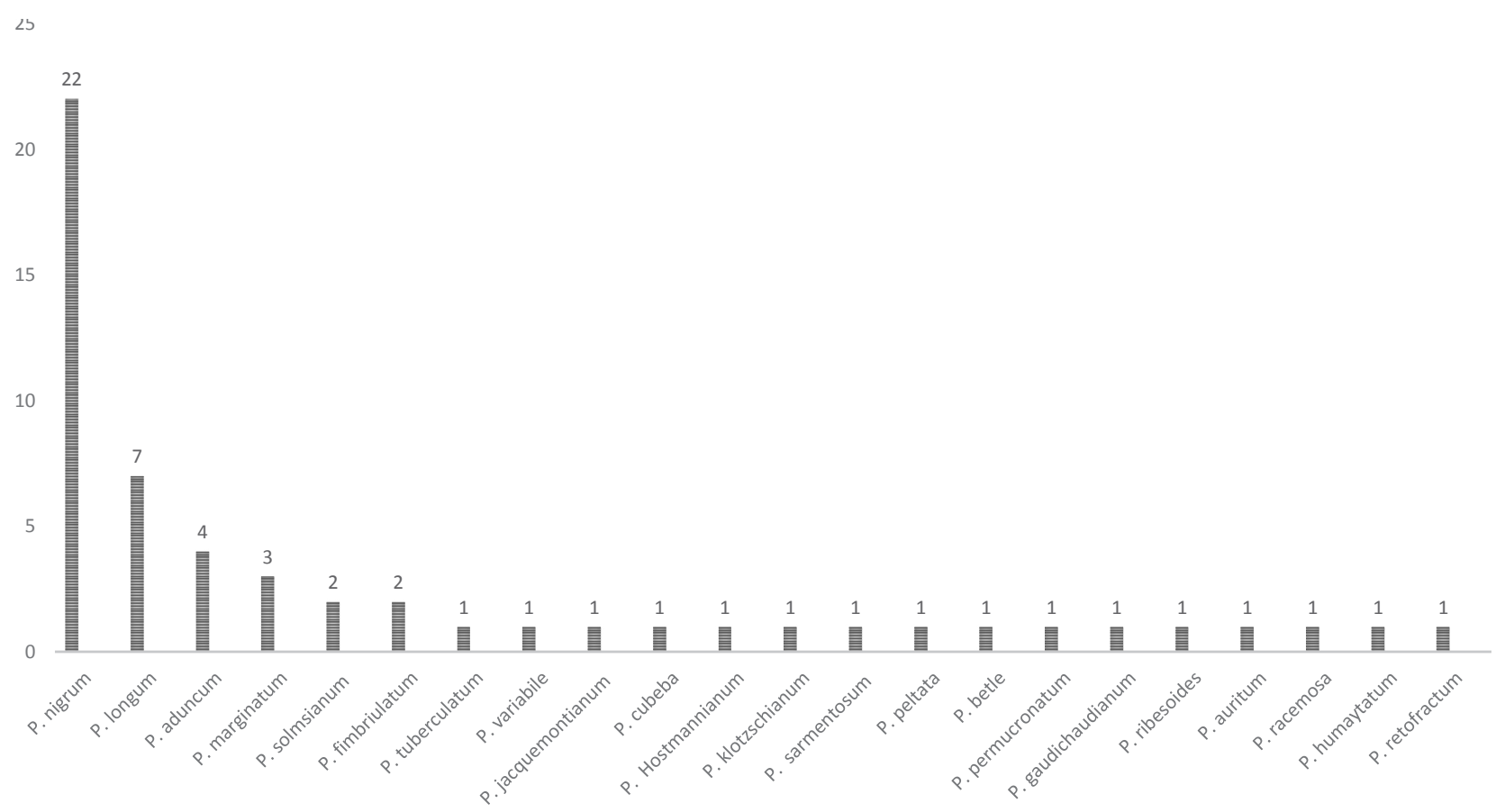

Fig. 4. Piper species with larvicidal activity against $A$. aegypti reported in Web of Science searching for topics (Piper) + (dengue) or $($ Piper $)+($ Aedes aegypti) until May 2013. vary significantly depending on the plant species, and especially, on the polarity of the solvent for extraction. The polarity of the solvents will determine which types of chemical compounds will be extracted from the complex natural matrixes (Ghosh et al. 2012). Many Piper extracts have been tested previously against different kinds of parasites and insects. Bio-guided isolation of secondary metabolites can be a useful tool in phytochemical research, once the biological activity is observed the isolation of target compounds can be accomplished with pharmacological accuracy (Lee 2005). This fractionation process can focus the active metabolites toward the pure compounds, limiting the wide range of possibilities of biological mechanism pathways. On the other hand, crude extracts or active sub-fractions could act by synergism processes, contributing to increasing the possibilities of effective mechanism actions by a variety of phytocompounds from different chemical classes. In literature sources, close to 1,200 plant species have been described that have potential insecticidal value; however, only 344 of these plant species exhibited mosquitocidal activity (Ghosh et al. 2012). According to Web of Science, 41 studies regarding Aedes aegypti have been carried out, 22 of them testing the larvicidal activity of the Piper species against $A$. aegypti (Figure 4). Most of all 
related works (22) are related to an active extract from Piper nigrum, essential oil and pure isolated secondary metabolites. Brazil is the country with the most works related to larvicidal activity of Piper derivatives and $A$. aegypti larvae (12) followed by Pakistan (11), India (4),
Panama (3), South Korea (3), Thailand (3) and others. In this context, the crude extracts and partitioned fractions of 13 Piper species were chemically studied and assayed against the dengue vector, Aedes aegypti, (Table 1). In most of the cases, the prior bio-guided

Table 1. Piper extracts and sub-fractions with larvicidal properties against $A$. aegypti.

\begin{tabular}{|c|c|c|c|c|}
\hline Piper species & Plant Material & Extract & Lethal Conc. & Ref \\
\hline P. aduncum & leaves & hexane extract & $\mathrm{LC}_{50}-0.20 \mathrm{mg} / \mathrm{cm}^{2}$ & Hidayatulfathi et al. 2004 \\
\hline P. aduncum & leaves & crude extract & active & Pohlit et al. 2004 \\
\hline P. betle & leaves & crude extract & $\mathrm{LC}_{50}-236.73 \mathrm{ppm}$ & Tennyson et al. 2012 \\
\hline P. cubeba & fruits & acetone fraction & very low activity & Murthy \& Rani 2009 \\
\hline P. fimbriulatum & leaves & crude extract & $\mathrm{LC}_{100}<30 \mu \mathrm{g} / \mathrm{mL}$ & Calderón et al. 2006 \\
\hline P. jacquemontianum & Leaves & Crude extract & $\mathrm{LC}_{50}>1000 \mu \mathrm{g} / \mathrm{mL}$ & Cruz et al. 2011 \\
\hline P. longum & fruits & crude EtOH extract & $\mathrm{LC}_{50}-2.23 \mathrm{ppm}$ & Chaithong et al. 2006 \\
\hline P. longum & fruits & crude EtOH extract & $\mathrm{LC}_{50}-0.26 \mu \mathrm{g} / \mathrm{fem}$ & Choochote et al. 2006 \\
\hline P. longum & fruits & crude $\mathrm{MeOH}$ extract & $\mathrm{LC}_{50}-40 \mathrm{ppm}$ & Lee 2005 \\
\hline P. longum & fruits & crude hexane extract & $\mathrm{LC}_{100}-10 \mathrm{ppm}$ & Lee 2005 \\
\hline P. longum & fruits & crude hexane extract & $\mathrm{LC}_{100}-0.017 \mathrm{ppm}$ & Sarita et al. 2011 \\
\hline P. nigrum & fruits & crude $\mathrm{MeOH}$ extract & $\mathrm{LC}_{50}-100 \mathrm{ppm}$ & Lee 2005 \\
\hline P. nigrum & fruits & crude EtOH extract & $\mathrm{LC}_{50}-0.98 \mathrm{ppm}$ & Simas et al. 2007 \\
\hline P. nigrum & black fruits & crude EtOH extract & $\mathrm{LC}_{50}-0.405 \mathrm{ppm}$ & Sarita et al. 2010 \\
\hline P. nigrum & white fruits & crude EtOH extract & $\mathrm{LC}_{50}-0.356 \mathrm{ppm}$ & Sarita et al. 2010 \\
\hline P. nigrum & fruits & crude extract & $\mathrm{LC}_{50}-1.84 \mu \mathrm{g} / \mathrm{mL}$ & Grzybowski et al. 2012 \\
\hline P. nigrum & fruits & crude extract & $\mathrm{LC}_{50}-2.26 \%$ & Nawaz et al. 2011 \\
\hline P. nigrum & roots & crude extract & $\mathrm{LC}_{50}-1.66 \mu \mathrm{g} / \mathrm{mL}$ & Ee et al. 2008 \\
\hline P. nigrum & roots & Ethyl acetate extract & $\mathrm{LC}_{50}-3.96 \mu \mathrm{g} / \mathrm{mL}$ & Ee et al. 2008 \\
\hline P. nigrum & roots & hexane extract & $\mathrm{LC}_{50}-0.45 \mu \mathrm{g} / \mathrm{mL}$ & Ee et al. 2008 \\
\hline P. nigrum & roots & choroform fraction & $\mathrm{LC}_{50}-0.37 \mu \mathrm{g} / \mathrm{mL}$ & Ee et al. 2008 \\
\hline P. peltata & roots & crude leaf extract & $\mathrm{LC}_{50}-398 \mu \mathrm{g} / \mathrm{mL}$ & Mongelli et al. 2002 \\
\hline P. retrofractum & fruits & crude extract & $\mathrm{LC}_{50}-79 \mathrm{ppm}$ & Chansang et al. 2005 \\
\hline P. ribesoides & fruits & crude extract & $\mathrm{LC}_{50}-8.13 \mathrm{ppm}$ & Chaithong et al. 2006 \\
\hline P. ribesoides & fruits & crude extract & $\mathrm{LC}_{50}-0.15 \mu \mathrm{g} / \mathrm{fem}$ & Choochote et al. 2006 \\
\hline P. sarmentosum & fruits & crude extract & $\mathrm{LC}_{50}-0.14 \mu \mathrm{g} / \mathrm{fem}$ & Choochote et al. 2006 \\
\hline P. sarmentosum & fruits & crude extract & $\mathrm{LC}_{50}-4.06 \mathrm{ppm}$ & Chaithong et al. 2006 \\
\hline P. tuberculatum & leaves & crude extract & active & Pohlit et al. 2004 \\
\hline P. variabile & leaves & crude extract & $\mathrm{LC}_{50}>1000 \mu \mathrm{g} / \mathrm{mL}$ & Cruz et al. 2011 \\
\hline
\end{tabular}


isolation of the pure active compounds was performed in order to obtain the pure compounds.

Piper nigrum is the most recognized and consumed Piper species in the world. In many countries, this species is considered the king of the spices; it is used in most of the food dishes because of its pungent principle, the amide, piperine. Most likely because of this, P. nigrum is also the most studied species in the Piperaceae family. Different parts of P. nigrum as well as its isolated metabolites have been used in active preparations with biological properties such as preservatives and insecticidal and larvicidal control agents (Ahmad et al. 2012).

At $100 \mathrm{ppm}$, the methanol extract of P. nigrum fruit showed strong larvicidal activity against $A$. aegypti. Further solvent fractionation also showed strong larvicidal activity in the hexaneand chloroform fractions. Additional bioassay-guided fractionation of this extract exhibited four active components: pellitorine, guineensine, pipercide, and retrofractaminde A (Lee 2005). Chansang et al. (2005) reported the larvicidal activity of the methanol crude extract of $P$. retrofractum; in this work, the $\mathrm{LC}_{50}$ value was $79 \mathrm{mg} / \mathrm{L}$. Another study evaluated possible active combinations of different botanical sources including Annona muricata seed and Piper nigrum fruit ethanolic extracts; these extracts are rich in acetogenins and piperamides, respectively. Individual bioassays of $P$. nigrum extracts indicated an $\mathrm{LC}_{50}$ value of $1.84 \mu \mathrm{g} / \mathrm{mL}$ against third instar larvae. The best combination was the $A$. muricata/P. nigrum extract combination at 9:1. The authors suggest that the synergism of this combination was responsible for the morphological effects that took place in the larvae's bodies that lead to their mortality (Grzybowski et al. 2012). Simas et al. (2007) reported on the fractionation of $P$. nigrum ethanol extract. Biological tests were carried out on pyrethroid-resistant Aedes aegypti larvae. The biomonitored assays led to the isolation of the larvicidal amides piperolein-A (1.46ppm) and piperine $(1.53 \mathrm{ppm}) . \mathrm{LC}_{50}$ values of the ethanol crude extract were only $0.98 \mathrm{ppm}$, significantly lower than methanol extract. Sarita et al. (2011) evaluated the larvicidal potential of piper fruits. Three extracts of Piper species were studied; long pepper (Piper longum L.), and black and white pepper from Piper nigrum were tested against different instars of a field-collected Indian strain of $A$. aegypti. The three extracts were active against
A. aegypti; however, the ethanolic extracts of black and white $P$. nigrum were less toxic than the extracts of $P$. longum. Against early fourth instar larvae, lethal $\mathrm{LC}_{50}$ values of ethanolic extracts of $P$. longum, white $P$. nigrum and black $P$. nigrum were $0.248,0.356$, and $0.405 \mathrm{ppm}$, respectively. Against third instar larvae; lethal $\mathrm{LC}_{50}$ values recorded of the three extracts were $0.022,0.015$, and $0.016 \mathrm{ppm}$, respectively.

In Malaysia, a chemical and biological study of P. nigrum roots indicated that the crude root extracts and pure piperine showed significant activity against A. aegypti larvae. The crude hexane, chloroform, ethyl acetate and methanol extracts of Piper nigrum displayed high toxicity towards the larvae; $\mathrm{LC}_{50}$ values were less than $4.0 \mu \mathrm{g} / \mathrm{mL}$. The crude hexane extract yielded an $\mathrm{LC}_{50}$ value of $0.45 \mu \mathrm{g} / \mathrm{mL}$; the crude chloroform extract with an $\mathrm{LC}_{50}$ value of $0.37 \mu \mathrm{g} / \mathrm{mL}$, and the crude ethyl acetate an $\mathrm{LC}_{50}$ value of $3.96 \mu \mathrm{g} / \mathrm{mL}$ while the methanol extract had an $\mathrm{LC}_{50}$ value of $1.66 \mu \mathrm{g} / \mathrm{mL}$. The pure isolated amide piperine also exhibited strong activity against the larvae with an $\mathrm{LC}_{50}$ value of $4.46 \mu \mathrm{g} / \mathrm{mL}$ (Ee et al. 2008). Nonpolar fractions probably displayed a higher effectiveness effect in this work because of their ability to extract a higher number of active larvicidal metabolites such as Piper amides from the crude extract. This higher activity coincides with the higher concentration of greater diversity of active amides and in turn, with the low polarity of the fractions and their possible enrichment with active metabolites such as Piper amides. Nawaz et al. (2011) also reported that the extracts from P. nigrum were effective against $A$. aegypti with low $\mathrm{LC}_{50}$ values $(2.26 \%$ and $8.4 \%)$ after $24 \mathrm{~h}$ and $48 \mathrm{~h}$ of exposure respectively. In terms of $\mathrm{LT}_{50}$, black pepper took $15 \mathrm{~h}$ to kill $84 \%$ of $50 \%$ of the tested population of $A$. aegypti. As a result, Piper nigrum extracts can kill adult mosquitoes and could be used as an environment friendly alternative to control mosquitoes.

Crude extracts of Piper longum were also subjected to phytochemical and biological assessments. Fruitderived materials $P$. longum were evaluated as larvicidal against fourth instar $A$. aegypti larvae. The crude methanol extract and the hexane fraction of $P$. longum fruit were active against the larvae; both extracts showed strong larvicidal activity and 100\% mortality. Through additional chromatographic procedures, the biologically active component of $P$. longum fruits was 
characterized as pipernonaline with an $\mathrm{LC}_{50}$ value $\mathrm{pf}$ $0.25 \mathrm{mg} / \mathrm{L}$ (Yang et al. 2002). The methanol extract activity, which was also reported for $P$. longum fruits, was responsible for a strong mosquito larvicidal activity at $40 \mathrm{ppm}$. Further solvent fractionation showed strong larvicidal activity in the hexane fraction, which showed $100 \%$ mortality at 40, 20, and $10 \mathrm{ppm}$. Chloroform fraction showed $31 \%$, and water fraction exhibited $15 \%$ mortality against $A$. aegypti at $40 \mathrm{ppm}$. Little activity was found in other organic solvent fractions (Lee 2005).

Chaithong et al. (2006) evaluated the larvicidal efficacy ethanol extracts of three Piper species; $P$. longum, $P$. ribesoides and $P$. sarmentosum against early fourth instar $A$. aegypti larvae. $L_{50}$ values of $8.13 \mathrm{ppm}$ were found for $P$. longum, 4.06 for $P$. sarmentosum and 2.23 for P. ribesoides. In another study, acetone extracts from eight plant species collected in India were tested for their larvicidal activity against $A$. aegypti $\mathrm{L}$. The buds of Piper cubeba L. were collected in India and chemically evaluated; the extracts exhibited toxicity against third instar larvae. The P. cubeba acetone extract displayed low activity and required a higher concentration to obtain 50\% toxicity (Murthy \& Rani 2009).

In Panama, one hundred fifty plant extracts representing 43 families, 73 genera, and 93 species were tested in a panel of antimalarial (Plasmodium falciparum W2), antileishmanial (Leishmania mexicana), antitrypanosomal (Trypanosoma cruq̨), and larvicidal (Aedes aegypti) screens. Of these 150 plant extracts, only one $(0.6 \%)$ Piper fimbriulatum showed larvicidal activity with $\mathrm{LC}_{100}$ values $<30 \mu \mathrm{g} / \mathrm{mL}$ (Calderón et al. 2006). In Guatemala, two native Piper species were chemically evaluated, and their dichloromethane and methanol extracts were tested for their biological activity. Dichloromethane extracts of P. jacquemontianum and the methanol extract of $P$. variabile were not active against $A$. aegypti larvae (Cruz et al. 2011). The adulticidal activity of methanol extracts of Piper aduncum from Malaysia was also tested against adult of Aedes aegypti (L.); the hexane fraction of its crude extract was effective as an insecticidal presenting $\mathrm{LC}_{50}$ and $\mathrm{LC}_{90}$ values of $0.20 \mathrm{mg} / \mathrm{cm}^{2}$ and $5.32 \mathrm{mg} / \mathrm{cm}^{2}$, respectively (Hidayatulfathi et al. 2004). Mongelli et al. (2002) evaluated the insecticidal activity of the leaves of Piperpeltata on $A$. aegypti larvae and reported that the larvicidal potential of roots crude extract presented an $\mathrm{LC}_{50}$ value of $398 \mu \mathrm{g} / \mathrm{mL}$. Mongelli et al. (2002) also conducted the fractionation of the active methanol extract. The biomonitored larvicidal fractionation isolated the catechol derivative, 4-nerolidylcatechol; this compound was effective against $A$. aegypti larvae with value of $\mathrm{LC}_{50}=9.1 \mu \mathrm{g} / \mathrm{mL}$. In India, the crude methanol leaf extract of three native plants were investigated. Piper betle crude extract was evaluated for Aedes aegypti larvicidal activity at concentrations varying from 62.5 to $1000 \mathrm{ppm}$, mortality was observed during 24 and 48 hours. The Piper betle was moderately active with $\mathrm{LC}_{50}$ values of 236.73 and $98.45 \mathrm{ppm}$ after 24 and 48 h, respectively (Tennyson et al. 2012).

\section{Larvicidal potential of isolated metabolites from} Piper species

Plant extracts and phytocompounds have been assessed as an alternative to toxic pesticides conventionally used for insect pests control. The biodegradability into nontoxic products of natural products make them appealing to find safer, effective and sustainable new insecticides that can be integrated into management programs, especially because of their commercial acceptance (Rimando \& Duke 2006). Unfortunately, research of bioactive natural products is sometimes restricted to only a few institutes and universities.

There are certain types of secondary metabolites that have greater insecticidal properties than all the other biologically active substances found in nature. Among all potential bioactive metabolites there are many different structures and chemical classes such as amides, limonoids, stilbenes, coumarins, sesquiterpenes, and quinones, which has the highest number of bioactive compounds. It should also be noted that the low $\mathrm{LC}_{50}$ values observed for some of these compound classes could feature as an alternative product with greater potential for their use as an A. aegypti control agent (Garcez et al. 2013).

Amides, a chemical metabolite class very common in Piperspecies, were the mostactive natural compounds against $A$. aegypti. Numerous active amides assayed for $A$. aegypti larvae were obtained from extracts of black pepper originally from tropical countries. These amides are typically a long chain of unsaturated amides formed by an acyl derivative component and an amine 
moiety. The long-chain unsaturated acyl component can be classified into two main structural types: (a) dienamines, derived from straight chain fatty acids and (b) a piperonal unit with chain extension by fatty acid (Rahman 2012). Some isolated metabolites from Piper species are shown in the (Figure 5). Amides (27) and lignans (3) are the most cited active chemical classes found in Piper species with larvicidal properties against dengue vector $A$. aegypti (Table 2). These are the chemicals most often found in Piper species, especially in P. nigrum, the most studied species from Piperaceae family (Rahman 2012, Siddiqui et al. 2003, 2004, 2005, Leite et al. 2012, Simas et al. 2004, 2007, Solis et al. 2005, Lee 2005, Da Silva et al. 2011). frames: the piperidine alkaloid and $\mathrm{N}$-isobutylamide alkaloids. The amide piperine is in the first group, with $\mathrm{LD}_{50}=5.10 \mu \mathrm{g} / \mathrm{mL}$ (Da Silva et al. 2011). This active compound was the first amide isolated from Piper species, especially from P. longum and P. nigrum, and underwent a wide range of biological activity studies (Parmar et al. 1997). On the other hand, are the amides pellitorine, guineensine, pipyahyine, pipnoodhine, pipercide, retrofractamide-A and refractoamide-D that come from N-isobutylamide alkaloids (Rahman 2012); all these isolated amides were tested against female adults of $A$. aegypti. In regards to the most toxic against female of $A$. aegypti, the insecticidal activity was more pronounced in pellitorine with $\left(\mathrm{LC}_{50}=0.92 \mu \mathrm{g} / \mathrm{mL}\right.$
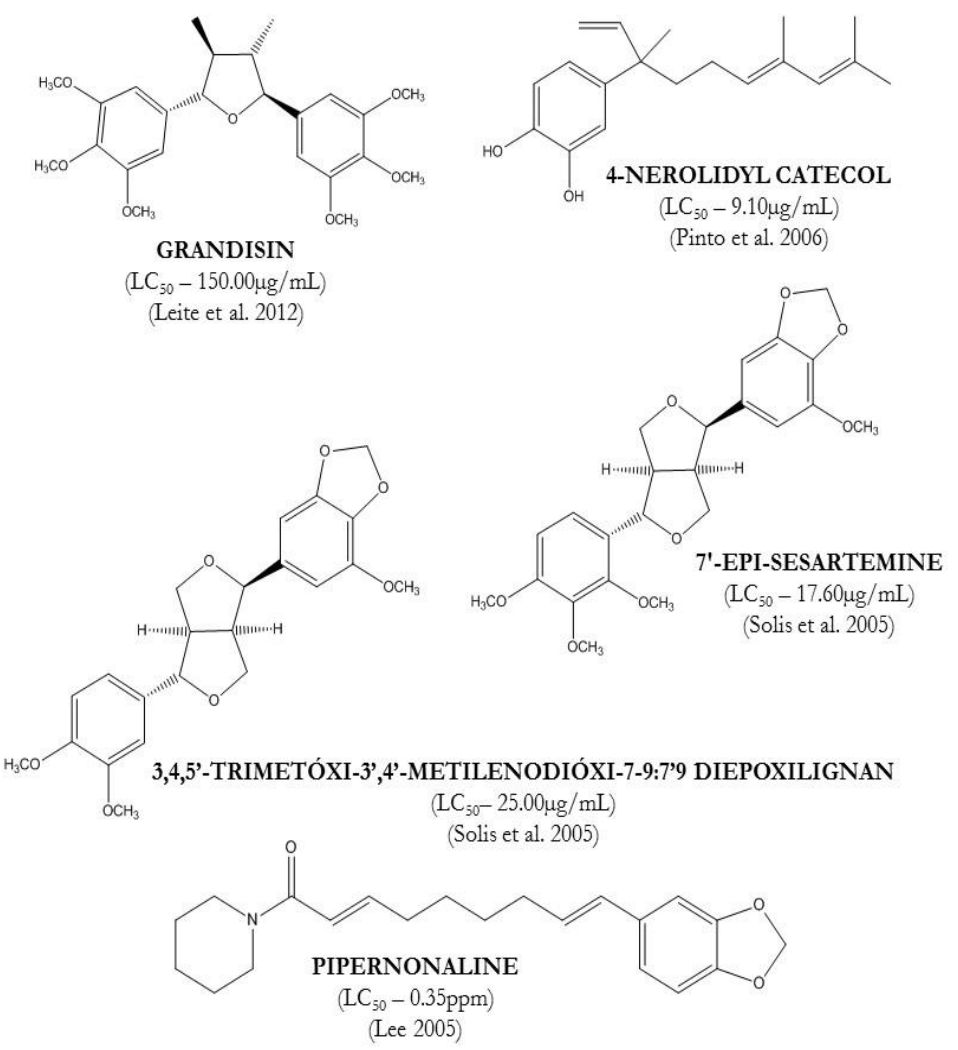
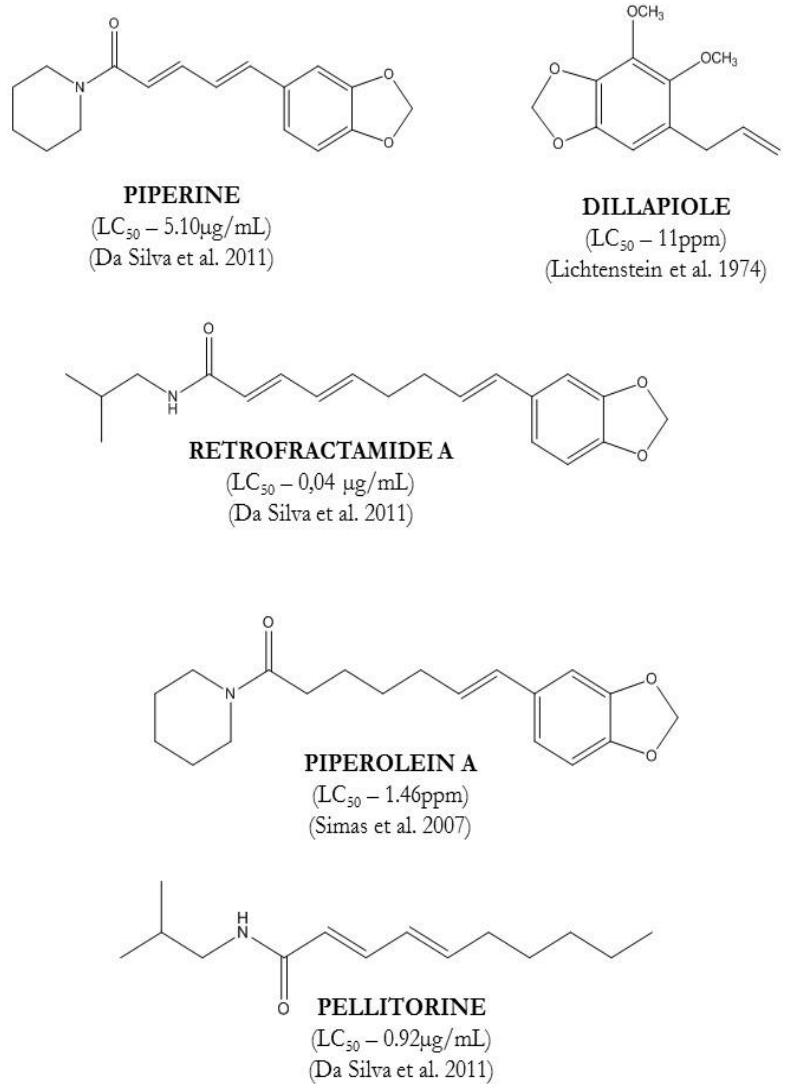

Fig. 5. Some isolated larvicidal metabolites from Piper species.

The insecticidal activity of $P$. nigrum fruits has shown a wide variety of active amides. In most cases, the structures are derived from two main chemical and $\mathrm{LC}_{50}=0.17 \mu \mathrm{g} /$ female), retrofractamide $\mathrm{A}\left(\mathrm{LC}_{50}\right.$ $=0.04 \mu \mathrm{g} / \mathrm{mL}$ and $\mathrm{LC}_{50}=1.5 \mu \mathrm{g} /$ female $)$, guineensine $\left(\mathrm{LC}_{50}=0.89 \mu \mathrm{g} / \mathrm{mL}\right.$ and $\mathrm{LC}_{50}=1.7 \mu \mathrm{g} /$ female $)$, and 
Table 2. Piper extracts and sub-fractions with larvicidal properties against $A$. aegypti.

\begin{tabular}{|c|c|c|c|c|}
\hline Active Metabolites & Plant Material & Piper species & Lethal Conc. & Ref \\
\hline dillapiole & leaves & P. aduncum & $\mathrm{LC}_{50}-11 \mathrm{ppm}$ & Lichtenstein et al. 1974 \\
\hline dillapiole & leaves & P. aduncum & $\mathrm{LC}_{50}-0.381 \mu \mathrm{g} / \mathrm{cm} 2$ & Pinto et al. 2012 \\
\hline 7'-epi-sesartemine & leaves & P. fimbriulatum & $\mathrm{LC}_{100}-17.60 \mu \mathrm{g} / \mathrm{mL}$ & Solis et al. 2005 \\
\hline $\begin{array}{l}\text { 3,4,5'-trimetóxi-3',4'- } \\
\text { metilenodióxi-7-9:7'9 diepoxilignan }\end{array}$ & leaves & P. fimbriulatum & $\mathrm{LC}_{100}-25.00 \mu \mathrm{g} / \mathrm{mL}$ & Solis et al. 2005 \\
\hline pipernonaline & fruits & P. nigrum & $\mathrm{LC}_{50}-0.35 \mathrm{ppm}$ & Lee 2005 \\
\hline piperine & fruits & P. nigrum & $\mathrm{LC}_{50}-5.10 \mu \mathrm{g} / \mathrm{mL}$ & Da Silva et al. 2011 \\
\hline piperine & fruits & P. nigrum & $\mathrm{LC}_{50}-4.46 \mu \mathrm{g} / \mathrm{mL}$ & Ee et al. 2008 \\
\hline piperine & fruits & P. nigrum & $\mathrm{LC}_{50}-1.53 \mathrm{ppm}$ & Simas et al. 2007 \\
\hline retrofractamide A & fruits & P. nigrum & $\mathrm{LC}_{50}-0,04 \mu \mathrm{g} / \mathrm{mL}$ & Da Silva et al. 2011 \\
\hline retrofractamide A & fruits & P. nigrum & $\mathrm{LC}_{50}-0.039 \mathrm{ppm}$ & Lee 2005 \\
\hline Refractoamide D & fruits & P. nigrum & $\mathrm{LC}_{50}-25 \mathrm{ppm}$ & Rahman 2012 \\
\hline pipsaeedine & fruits & P. nigrum & $\mathrm{LC}_{50}-45 \mathrm{ppm}$ & Siddiqui et al. 2004 \\
\hline pipbinine & fruits & P. nigrum & $\mathrm{LC}_{50}-40 \mathrm{ppm}$ & Siddiqui et al. 2004 \\
\hline pipercide & fruits & P. nigrum & $\mathrm{LC}_{50}-0.10 \mathrm{ppm}$ & Lee 2005 \\
\hline guineensine & fruits & P. nigrum & $\mathrm{LC}_{50}-0.89 \mu \mathrm{g} / \mathrm{mL}$ & Da Silva et al. 2011 \\
\hline pipyahyine & fruits & P. nigrum & $\mathrm{LC}_{50}-30.00 \mu \mathrm{g} / \mathrm{mL}$ & Siddiqui et al. 2004 \\
\hline pellitorine & fruits & P. nigrum & $\mathrm{LC}_{50}-0.92 \mu \mathrm{g} / \mathrm{mL}$ & Da Silva et al. 2011 \\
\hline pipnoohine & fruits & P. nigrum & $\mathrm{LC}_{50}-35.00 \mu \mathrm{g} / \mathrm{mL}$ & Siddiqui et al. 2004 \\
\hline pipwaqarine & fruits & P. nigrum & $\mathrm{LC}_{50}-30 \mathrm{ppm}$ & Siddiqui et al. 2005 \\
\hline tert-butyldodecadienamide & fruits & P. nigrum & $\mathrm{LC}_{50}-15 \mathrm{ppm}$ & Rahman 2012 \\
\hline tert-butylhexadecadienamide & fruits & P. nigrum & $\mathrm{LC}_{50}-25 \mathrm{ppm}$ & Rahman 2012 \\
\hline piperanine & fruits & P. nigrum & $\mathrm{LC}_{50}-17 \mathrm{ppm}$ & Rahman 2012 \\
\hline $\begin{array}{l}\text { methylenedioxyphenylnon } \\
\text { atrienoylpyrrolidine }\end{array}$ & fruits & P. nigrum & $\mathrm{LC}_{50}-20 \mathrm{ppm}$ & Rahman 2012 \\
\hline $\begin{array}{l}\text { methylene dioxyphenylund } \\
\text { ecatrienoylpiperidine }\end{array}$ & fruits & P. nigrum & $\mathrm{LC}_{50}-25 \mathrm{ppm}$ & Rahman 2012 \\
\hline tert-butylhexadecadienamide & fruits & P. nigrum & $\mathrm{LC}_{50}-25 \mathrm{ppm}$ & Rahman 2012 \\
\hline [(2E,4E)-octadienoyl]-N-isobutylamide & fruits & P. nigrum & $\mathrm{LC}_{50}-23 \mathrm{ppm}$ & Rahman 2012 \\
\hline (2E,4E)-eicosadienoyl-N-isobutylamide & fruits & P. nigrum & $\mathrm{LC}_{50}-25 \mathrm{ppm}$ & Rahman 2012 \\
\hline [(2E)-hexadecanoyl]-pyrrolidine & fruits & P. nigrum & $\mathrm{LC}_{50}-64 \mathrm{ppm}$ & Rahman 2012 \\
\hline $\begin{array}{l}{[(2 \mathrm{E}, 4 \mathrm{E}) \text {-octadecadienoyl }]-\mathrm{N} \text { - }} \\
\text { isobutylamide }\end{array}$ & fruits & P. nigrum & $\mathrm{LC}_{50}-25 \mathrm{ppm}$ & Rahman 2012 \\
\hline piperolein-A & fruits & P. nigrum & $\mathrm{LC}_{50}-1.46 \mathrm{ppm}$ & Simas et al. 2007 \\
\hline pipzorine & fruits & P. nigrum & $\mathrm{LC}_{100}-70.00 \mathrm{ppm}$ & Rahman 2012 \\
\hline piptigrine & fruits & P. nigrum & $\mathrm{LC}_{50}-15 \mathrm{ppm}$ & Rahman 2012 \\
\hline sarmentine & fruits & P. nigrum & $\mathrm{LC}_{100}-27.00 \mathrm{ppm}$ & Rahman 2012 \\
\hline pipgulzarine & fruits & P.nigrum & $\mathrm{LC}_{100}-6.00 \mathrm{ppm}$ & Siddiqui et al. 2003 \\
\hline 4-nerolidyl catecol & fruits & P. peltata & $\mathrm{LC}_{50}-9.10 \mu \mathrm{g} / \mathrm{mL}$ & Pinto et al. 2006 \\
\hline grandisin & leaves & P. solmsianum & $\mathrm{LC}_{50}-150.00 \mu \mathrm{g} / \mathrm{mL}$ & Leite et al. 2012 \\
\hline
\end{tabular}


pipercide $\left(\mathrm{LC}_{50}=0.1 \mu \mathrm{g} / \mathrm{mL}\right.$ and $\mathrm{LC}_{50}=2.0 \mu \mathrm{g} /$ female) (Da Silva et al. 2011). Regrettably, despite the low $\mathrm{LC}_{50}$ of the natural amides, the potency of the reference chemical, chlorpyrifos, with an $\mathrm{LC}_{50}$ value of $0.0014 \mu \mathrm{g} /$ female for $24 \mathrm{~h}$ was very low. In the nonpolar petroleum ether extract of dried ground fruits of Piper nigrum, the isolated amides pipnoohine, and pipyahyine exhibited toxicity at 35.0 and $30.0 \mathrm{ppm}$, respectively, against fourth instar larvae of Aedes aegypti (Siddiqui et al. 2004). The biomonitored fractionation of Piper nigrum ethanol fruits extract collected in the Amazon region of Brazil, prompted the isolation of larvicidal amides piperolein- $A$ and piperine; these compounds were tested against pyrethroid-resistant Aedes aegypti. Ethanol extract $\left(\mathrm{LC}_{50}=0.98 \mathrm{ppm}\right)$ was the most toxic, followed by piperolein-A $\left(\mathrm{LC}_{50}=1.46 \mathrm{ppm}\right)$ and piperine $\left(\mathrm{LC}_{50}=1.53 \mathrm{ppm}\right.$ ) (Simas et al. 2007).

Amides can also be found in the roots of Piper nigrum. Chemical investigations revealed that the amides piperine, sylvamide and 2,4-tetradecadienoic acid iso-butyl amide are the main constituent amides isolated from the roots of P. nigrum. In this work, piperine exhibited $\mathrm{LC}_{50}$ values of $4.46 \mu \mathrm{g} / \mathrm{mL}$ against A. aegypti (Ee et al. 2008).

As previously discussed, the fruits of Piper nigrum have a high diversity of bioactive amides. The insecticidal amide, pipwaqarine was isolated from nonpolar fractions of petroleum ether and ethyl acetate fractions of dried ground fruits; it yielded $\mathrm{LC}_{50}$ values of $30 \mathrm{ppm}$ against fourth instar Aedes aegypti larvae (Siddiqui et al. 2005). Ethanol extracts of fruits have shown potent insecticidal activity in recent studies; several compounds have been isolated including the amides pipkirine and wisanine. Piptigrine was isolated from the dried ground fruits of P. nigrum; it presented an $L_{50}$ value of $15.0 \mathrm{ppm}$ against fourth instar larvae of $A$. aegypti (Rahman 2012). The methanol extract of dried and grounded Piper nigrum fruits yielded 14 compounds, 13 of which were amides. In total, two new isomeric insecticidal amides, pipsaeedine and pipbinine, and 11 known amides as well as piptaline were isolated. Pipsaeedine $\left(\mathrm{LC}_{50}=45.0 \mathrm{ppm}\right)$ and pipbinine $\left(\mathrm{LC}_{50}=40.0 \mathrm{ppm}\right)$ were the most toxic compounds against fourth instar A. aegypti larvae (Siddiqui et al. 2004). In 2003, the larvicidal pipgulzarine, pipzorine, and piptahsine, was isolated from the dried fruits of Piper nigrum along with four known amides, N-isobutyl-(2E,4E,14Z)eicosatrienamide, pellitorine, pipercide, piperine and sarmentine. Pipgulzarine was very toxic to the larvae with an $\mathrm{LC}_{100}$ value of $6.00 \mathrm{ppm}$, followed by sarmentine with $\mathrm{LC}_{100}=27.00 \mathrm{ppm}$; pipzorine was 10 times less effective, with an $\mathrm{LC}_{100}$ value of $70.00 \mathrm{ppm}$ (Siddiqui et al. 2003). Siddiqui and colleagues also reported a myriad of amides with larvicidal toxicity isolated from fruits of P. nigrum purchased from the local market in Karachi. Of these amides, tert-butyldodecadienamid was found to be a larvicidal, with toxic effects in a concentration of $15 \mathrm{ppm}$ while piperanine was also toxic with an $\mathrm{LC}_{50}$ value of $17 \mathrm{ppm}$. The following amides methylenedioxyphenylnonatrienoylpyrrolidine, [(2E,4E)-octadienoyl]-N-isobutylamide, tert-butylhexadecadienamide and methylenedioxyphenylundecatrienoylpiperidine, and (2E,4E)-eicosadienoyl-N-isobutylamide showed a similar arvicidal activity of $20 \mathrm{ppm}$, while the amide [(2E)-hexadecanoyl]-pyrrolidine was the less effective with an LC $_{50}$ value of 64ppm (Rahman 2012).

The lignan, 3,4,5'-trimethoxy-3',4'methylenedioxy-7,9':7',9 diepoxylignan together with 7'-epi-sesartemin and diayangambin and the flavonoid 5-hydroxy-7,4'-dimethoxyflavone, were isolated from the leaves of Piper fimbriulatum. The most active compounds assayed against $A$. aegypti larvae was the lignan 7'-Epi-Sesartemin that showed pronounced larvicidal activity against Aedes aegypti $\left(\mathrm{LC}_{100}=17.6\right.$ $\mu \mathrm{g} / \mathrm{mL}$ ), followed by the 3,4,5'-trimethoxy-3',4'methylenedioxy-7,9':7',9 diepoxylignan with $\mathrm{LC}_{100}=$ $25.00 \mu \mathrm{g} / \mathrm{mL}$ (Solis et al. 2005). The lignan, grandisin isolated from leaves of Piper solmsianum collected in Brazil was reported as a larvicidal compound; this is the lignan of this species most frequently reported. Grandisin caused third instar A. aegypti larvae mortality with $\mathrm{LC}_{50}$ value of $150 \mu \mathrm{g} / \mathrm{mL}$. Larvae treated with grandisin showed an $\mathrm{LC}_{50}$ value of $50 \mu \mathrm{g} / \mathrm{mL}$ and underwent morphological body changes, with intense tissue destruction and cell disorganization (Leite et al. 2012). The treatment of L1 larvae of $A$. aegypti with grandisin presented $100 \%$ larval mortality at a concentration of $100 \mu \mathrm{g} / \mathrm{mL}$ (Cabral et al. 2009).

Bioactive amides were also found in Piper longum. The larvicidal amides piperidine, pipernonaline, piperoctadecalidine, pellitorine, guineensine, pipercide, and retrofractaminde had previously been isolated 
from this species. The highest larvicidal activities were presented by pipercide and retrofractamide $A$ with $\mathrm{LC}_{50}$ values 0.10 and $0.039 \mathrm{ppm}$ against $A$. aegypti, respectively while pipernonaline was less effective with an $\mathrm{LC}_{50}$ value of $0.35 \mathrm{ppm}$ (Lee 2005). In another study using $P$. longum, pipernonaline showed an $\mathrm{LC}_{50}$ value of $0.25 \mathrm{mg} / \mathrm{L}$. In this report, no larvicidal activity was observed with the amides piperettine, piperine, or piperlongumine (Yang et al. 2002).

The insecticidal activity of the leaves of Piper peltata (Pothomorphe peltata) was evaluated on $A$. aegypti larvae. The methanol extract was chemically fractionated. The larvicidal biomonitoring led to the isolation of a catechol derivative: 4-nerolidylcatechol. This compound showed $\mathrm{LC}_{50}$ values of $9.1 \mu \mathrm{g} / \mathrm{mL}$ against Aedes aegypti larvae (Mongelli et al. 2002). Another natural occurring compound, dillapiole, a phenylpropanoid isolated from essential oil from leaves of Piper aduncum, was assayed in vivo against larvae and pupae of $A$. aegypti. The pure active metabolite was reported as a natural insecticide compound with $\mathrm{LC}_{50}=11 \mathrm{ppm}$ (Lichtenstein et al. 1974) and $\mathrm{LC}_{50}$ of $0.381 \mu \mathrm{g} / \mathrm{cm}^{2}$ (Pinto et al. 2012) against A. aegypti. The mortality, oviposition, chromosome breakage, and anaphase bridges were significantly greater in the extract treatments in concentrations of 200 and 400 $\mu \mathrm{g} / \mathrm{mL}$ than in the controls. The genotoxic effects and larvicidal activity of dillapiole described here suggest that this natural product may be a useful alternative for the control of $A$. aegypti (Rafael et al. 2008). Based upon these results and earlier findings, bioactive compounds derived from Piper may be useful to develop a lead product for potentially safer fungicidal, insecticidal, and mosquito larvicidal agents.

The use of larvicidal essential oils from the Piper species against $A$. aegypti

Literature sources on the genus Piper shows high variability in the chemical composition of species with active essential oils. In this study, a total of 14 species were potentially toxic against $A$. aegypti. The species featured in the literature sources are: P. gaudichandianum, $P$. betle, $P$. tuberculatum, $P$. longum, $P$. nigrum, $P$. hostmannianum, P. aduncum, P. klotzschianum, P. humaytatum, P. racemosa, $P$. auritum, $P$. marginatum, $P$. sarmentosum and $P$. permucronatum. The most common components found in the Piper species studied are camphor, apiole, myristicin, safrole, sarisan, dillapiole, linalool, nerolidol, $\alpha$ and $\beta$-pinene, $\alpha$-humulene, $\beta$-caryophyllene, as well as propenyphenols. The larvicidal activity of the essential oils of Piper species is shown in Table 3.

Piper aduncum is the most studied Piper specie with larvicidal property against $A$. aegypti larvae. In Brazil, the essential oils from specimens of Piper aduncum can be found in various chemotypes depending on the region (Lara Junior et al. 2012). In the Brazilian Amazon region and North Brazil, the essential oil of P. aduncum leaves is rich in dillapiole (35-90\%), a phenylpropene derivative, while in Southeastern Brazil, in the Atlantic Forest they contain no dillapiole only terpenes such as (E)-nerolidol and linalool. In this study, dillapiole rich oil (95.0-98.9\%) was tested against $A$. aegypti larvae and adult insects. The results showed mortality of $100 \%$ of larvae after $48 \mathrm{~h}$ at a concentration of $100 \mathrm{ppm}$, and a mortality of $100 \%$ of the adult insects after 30 min at a concentration of $600 \mathrm{ppm}$ (Almeida et al. 2009). Isomeric isodillapiole showed no significant activity. The pure active metabolite proved a natural insecticide compound with $\mathrm{LC}_{50}=11 \mathrm{ppm}$ against A. aegypti (Lichtenstein et al. 1974). Literature sources reported that dillapiole, usually isolated from essential oils from the leaves of $P$. aduncum, has insecticidal, fungicidal and antimicrobial activities. This compound and its more stable reduced derivative dihydrodillapiole are used individually or in combination insecticidal formulations. It was observed that in treatments using 200 and $400 \mu \mathrm{g} / \mathrm{mL}$ of dillapiole in larvae samples of A. aegypti produced nuclear abnormalities in cells' pupae; several cellular abnormalities were observed (Rafael et al. 2008). The bio-efficacy of P. aduncum L. essential oil formulated in aerosol was also evaluated against A. aegypti. An aerosol spray test was carried out, and the knockdown effect was assessed within 20 minutes of exposure. The results showed that the essential oil induced a significantly higher mortality in $A$. aegypti $(80 \%)$ while the commercial aerosol spray composed by $0.09 \%$ prallethrin and $0.05 \% \mathrm{~d}$-phenothrin caused a $97.7 \%$ mortality of $A$. aegypti (Norashiqin et al. 2011). Based on this data, P. aduncum essential oil has the potential to be used as an aerosol spray.

Dillapiole is also the major component of $P$. permucronatum $(54.70 \%)$. The main components of P. permucronatum are myristicin (25.61\%), dillapiole $(54.70 \%)$, asaricin $(8.55 \%)$ and elemicin $(9.92 \%)$. This 
Table 3. Piper crude essential oils with larvicidal activity against $A$. aegypti.

\begin{tabular}{|c|c|c|c|c|}
\hline Piper species & Plant Material & Active sample & Lethal Conc. & Ref \\
\hline P. aduncum & leaves & essential oil & $\mathrm{LC}_{50}-100 \mathrm{ppm}$ & Almeida et al. 2009 \\
\hline P. aduncum & leaves & essential oil & $\mathrm{LC}_{50}-0.0057 \%$ & Leyva et al. 2009 \\
\hline P. auritum & leaves & essential oil & $\mathrm{LC}_{50}-0.0017 \%$ & Leyva et al. 2009 \\
\hline P. betle & leaves & essential oil & $\mathrm{LC}_{50}-48 \mathrm{ppm}$ & Nagori et al. 2011 \\
\hline P. gaudichaudianum & leaves & essential oil & $\mathrm{LC}_{50}-121.00 \mu \mathrm{g} / \mathrm{mL}$ & Morais et al. 2007 \\
\hline P. hostmannianum & leaves & essential oil & $\mathrm{LC}_{50}-54.00 \mu \mathrm{g} / \mathrm{mL}$ & Morais et al. 2007 \\
\hline P. bumaytatum & leaves & essential oil & $\mathrm{LC}_{50}-156.00 \mu \mathrm{g} / \mathrm{mL}$ & Morais et al. 2007 \\
\hline P. klotzschianum & seeds & essential oil & $\mathrm{LC}_{50}-13.27 \mu \mathrm{g} / \mathrm{mL}$ & Nascimento et al. 2013 \\
\hline P. klotzschianum & roots & essential oil & $\mathrm{LC}_{50}-10.00 \mu \mathrm{g} / \mathrm{mL}$ & Nascimento et al. 2013 \\
\hline P. longum & fruits & essential oil & $\mathrm{LC}_{50}-6.35 \mu \mathrm{g} /$ female & Chaiyasit et al. 2006 \\
\hline P. marginatum & fruit & essential oil & $\mathrm{LC}_{50}-20 \mathrm{ppm}$ & Autran et al. 2009 \\
\hline P. marginatum & fruit & essential oil & $\mathrm{LC}_{50}-8,29 \mu \mathrm{g} / \mathrm{mL}$ & Costa et al. 2010 \\
\hline P. nigrum & fruits & essential oil & $\mathrm{LC}_{50}-9.1 \mathrm{ppm}$ & Massebo et al. 2009 \\
\hline P. nigrum & fruits & essential oil & $\mathrm{LC}_{50}-2.26 \%$ & Nawaz et al. 2011 \\
\hline P. permucronatum & leaves & essential oil & $\mathrm{LC}_{50}-36.00 \mu \mathrm{g} / \mathrm{mL}$ & Morais et al. 2007 \\
\hline P. racemosa & leaves & essential oil & $\mathrm{LC}_{50}-0.0027 \%$ & Leyva et al. 2009 \\
\hline P. sarmentosum & leaves & essential oil & $\mathrm{LC}_{50}-16.03 \mathrm{ppm}$ & Intirach et al. 2012 \\
\hline P. tuberculatum & leaves & essential oil & $\mathrm{LC}_{50}-106.3 \mu \mathrm{g} / \mathrm{mL}$ & Lavor et al. 2012 \\
\hline
\end{tabular}

essential oil proved to be potent with $\mathrm{LC}_{50}=36 \mu \mathrm{g} / \mathrm{mL}$ against the parasite larvae. In P. hostmanianum, dillapiole is the third major constituent found in $7.66 \%$. The main volatile components of this species are asaricin (27.37\%), myristicin $(20.26 \%)$, and dillapiole $(7.66 \%)$. $P$. bostmanianum also has larvicidal properties against the dengue vector with $\mathrm{LC}_{50}=54 \mu \mathrm{g} / \mathrm{mL}$ (Morais et al. 2007). Both species are widely distributed in the in the Amazon Forest, in North Brazil.

Many biological activities have been reported involving Piper nigrum fruits. Its essential oil is composed by caryophyllene (54.92\%), caryophyllene oxide $(13.26 \%), \alpha$-caryophyene $(3.97 \%)$, copaene $(2.90 \%)$, cadina-1 (10), 4-diene $(2.61 \%)$, tumerone $(2.38 \%)$. Larvicidal property was reported about this oil with $\mathrm{LC}_{50}=9.1 \mathrm{ppm}$ (Massebo et al. 2009). Another study assessed the repellency potential of these volatile fractions. A high degree of repellency was obtained with $P$. nigrum (2.3h), with a 3-minute exposure period to $A$. aegyti while $P$. betle was (1.3h). The repellency and ovipositional deterrent activity of essential oils and standard repellents were studied for gravid $A$. aegypti. The oviposition deterrent effects of essential oils showed a moderate degree of deterrence for P. nigrum (82\%) and P. betle (78.9\%) essential oils (Tawatsin et al. 2006). The volatile oils from fresh roots, stems, leaves and seeds of P. klotzschianum were chemically studied and tested against fourth instar A. aegypti larvae. The main chemical constituent identified from different parts of this plant species was 1-butyl-3,4-methylenedioxybenzene, followed by the 2,4,5-trimethoxy-1-propenylbenzene found in the root and also 1-butyl-3,4-methylenedioxybenzene found in the stems and leaves. The main compounds found in the seeds were 1-butyl-3,4-methylenedioxybenzene, 
limonene and $\alpha$-phellandrene. The activity against fourth instar $A$. aegypti larvae was observed in the essential oils from the seeds $\left(\mathrm{LC}_{50}=13.27 \mu \mathrm{g} / \mathrm{mL}\right)$ and roots $\left(\mathrm{LC}_{50}=10.0 \mu \mathrm{g} / \mathrm{mL}\right)$ of this plant (Nascimento et al. 2013). The larvicidal activity of essential oils from the leaves of Piper tuberculatum was evaluated using third instar larvae of $A$. aegypti showing $\mathrm{LC}_{50}=$ $106.3 \mu \mathrm{g} / \mathrm{mL}$. Its essential oil was mainly composed by monoterpenes such as $\alpha$ - and $\beta$-pinene, transocimene and the sesquiterpenes, $\beta$-caryophyllene and $\beta$-farnesene (Lavor et al. 2012). Sesquiterpenes were also found in great quantity in the essential oils from P. gaudichaudianum: viridiflorol (27.50\%), aromadendrene $(15.55 \%), \beta$-selinene $(10.50 \%)$, and selin-11-en-4-alfaol $(8.48 \%)$ as well as in $P$. bumaytanum are $\beta$-selinene $(15.77 \%)$, caryophyllene oxide $(16.63 \%)$, spathulenol (6.33\%), and $\beta$-oplopenone (6.02\%). The essential oils of both species were also tested against $A$. aegyptilarvae. The results of larvicidal tests for $P$. gaudichaudianum and $P$. bumaytanum showed $\mathrm{LC}_{50}$ values of $121 \mu \mathrm{g} /$ $\mathrm{mL}$ and $156 \mu \mathrm{g} / \mathrm{mL}$, respectively (Morais et al. 2007). The insecticidal activity of $P$. longum essential oils was tested using topical test application on two populations of Aedes aegypti in pyrethroid-susceptibility bioassays. The results revealed that this essential oil displayed a promising efficacy against both laboratory and natural field strains of $A$. aegypti. The highest potential was established from long pepper with an $\mathrm{LC}_{50}$ value of $6.21 \mu \mathrm{g} / \mathrm{mg}$.female for the laboratory strain and $6.35 \mu \mathrm{g} / \mathrm{mg}$.female for the field strain, respectively. The major compound identified in this species was sesquiterpene $\beta$-caryophyllene, followed by 3 -carene, eugenol and limonene (Chaiyasit et al. 2006). In Brazil, the essential oils of leaves, stems and inflorescences of P. marginatum, harvested in the Atlantic forest, were analyzed, and they revealed the presence of major compounds asarone and patchouli. The essential oils from fruits exhibited potent activity against fourth instar larvae of $A$. aegypti with $\mathrm{LC}_{10}$ and $\mathrm{LC}_{50}$ values of 13.8 and $20.0 \mathrm{ppm}$, respectively. However, the essential oil of the fruit had no effect on the oviposition at a concentration of $50 \mathrm{ppm}$ (Autran et al. 2009). The larvicidal potency of the essential oils of $P$. auritum and $P$. racemosa collected in Cuba were assessed. The essential oils from the leaves of $P$. auritum and $P$. racemosa were active, in low concentrations, against third instar larvae of $A$. aegypti with $\mathrm{LC}_{50}=0.0017 \%$ and $\mathrm{LC}_{50}=0.0027 \%$ respectively. P. auritum essential oil is mainly composed of safrole (93.24\%) and miristicine (4.34\%), while the major compounds of $P$. racemosa are 4-terpineol (20.7\%), 1,8-cineol (20.4\%), eugenol $(10.7 \%)$ and $\alpha$-terpineol (10.0\%) (Leyva et al. 2009).

Many isolated components from essential oils have been tested and displayed distinct larvicidal activity. In the essential oil mixture, the combination of these terpenes and arylpropanoids can act, in some cases, in synergism increasing the toxic effect against the parasites. Chantraine et al. (1998) and Simas et al. (2004) reported the larvicidal activity for E-nerolidol in $A$. aegpti, with a value of $\mathrm{LC}_{50}(9.0 \mathrm{ppm})$ and $\left(\mathrm{LC}_{50}\right.$ $=17.0 \mathrm{ppm}$ ), respectively. Nerolidol is usually found in the essential oils of the Piper species and may be used in many topical formulations can increase the absorption of lipophilic drugs into membrane cells (El-Katan et al. 2001). The sesquiterpene farnesol showed larvicidal activity with $\mathrm{LC}_{50}=13 \mathrm{ppm}$, and monoterpene geraniol was found to be less active ( $\mathrm{LC}_{50}=81.6 \mathrm{ppm}$ ), while linalool was scarcely active with $\mathrm{LC}_{50}>100$ as well as menthol. The phenylpropanoids safrole, eugenol and cinnamic aldehyde were active with $\mathrm{LC}_{50}$ of 49.0, 44.5 and $24.4 \mathrm{ppm}$, respectively. Other monoterpenes were also tested such as $\beta$-pinene $\left(\mathrm{LC}_{50}=42.5 \mathrm{ppm}\right)$, $\alpha$-pinene $\left(\mathrm{LC}_{50}=74.3 \mathrm{ppm}\right)$ and carvone $\left(\mathrm{LC}_{50}=43.8\right.$ ppm) (Simas et al. 2004). The essential oils proved to be an efficient alternative to control and eradicate mosquito vectors. Volatile aromatic compounds are useful to repel and eradicate $A$. aegypti adult mosquitoes indoors. Although the reported activity of these oils is considered high, when compared to synthetic larvicides like temephos with $\mathrm{LC}_{50}$ and $\mathrm{LC}_{90}$ values 0.0177 and $0.0559 \mu \mathrm{g} / \mathrm{mL}$, respectively, these essential oils show much lower activity, (Becker 2010). In this context, essential oils could be used as an adjuvant in repellent formulations to increase their efficacy and decrease their toxicity to humans.

\section{Conclusions}

Bio-insecticides have a great potential to find low-risk options, from an ecological point-of-view, to control insects. Existing literature presents several examples of effective, natural metabolites that could be used in pest control plans. Finding an environmentally friendly mosquito-control management plan using phytocompounds will not completely replace synthetic insecticides. Natural compounds are perishable, and 
higher concentration doses are needed to effectively eliminate insects. The best alternative is to use these compounds as a supplement to optimize and increase the sustainability of current integrated pest control strategies. Moreover, the composition of many of these extracts and essential oils is very complex making it more difficult for the pest to develop resistance in comparison with synthetic insecticides. The risks to environmental biodiversity must be considered when using plant material as a source of bioactive compounds; endangered species must be avoided and biomass must be limited. An ideal insecticide plant would be perennial, widely distributed and prevalent in large amounts in nature or easily cultivated, using renewable plant parts. The species Piper nigrum, Piper aduncum and Piper longum, may be a feasible alternative source of larvicidal metabolites to control dengue mosquitoes. These species are distributed widely in tropical countries and are well adapted even in cultivated areas. In total, 32 studies were reported involving the biological activity of these species. Once these species reach are arboreal size from 4-5 meters in height, $P$. nigrum, $P$. aduncum and $P$. longum are of particular interest. All of the compounds tested that showed promise were obtained from aerial parts of the plant, especially from the fruits. Active amides and lignans from Piper species were abundant in these species and could be applied in the future used as a supplement to synthetic insecticides and also as a model for new active larvicidal compounds in the synthesis and studies of molecular improvement.

\section{Acknowledgments}

This work was supported by CAPES and CNPq.

\section{Conflicts of interests}

The authors declare no conflicts of interests.

\section{References}

Ahmad N, Fazal H, Abbasi BH, Farooq S, Mohammad A, Khan M A (2012) Biological role of Piper nigrum $\mathrm{L}$. (Black pepper): A review. Asian Pacific Journal of Tropical Biomedicine 2012: S1945-S1953 doi: 10.1016/S22211691(12)60524-3

Almeida RRP, Souto RNP, Bastos CN, da Silva MHL, Maia JGS (2009) Chemical Variation in Piper aduncum and
Biological Properties of Its Dillapiole-Rich Essential Oil. Chemistry \& Biodiversity 6(9):1427-1434 doi:10.1002/ cbdv.200800212

Autran ES, Neves IA, da Silva CSB, Santos GKN, da Camara CAG, Navarro DMAF (2009) Chemical composition, oviposition deterrent and larvicidal activities against Aedes aegypti of essential oils from Piper marginatum Jacq. (Piperaceae). Bioresource Technology 100(7):2284-2288 doi: 10.1016/j.biortech.2008.10.055

Becker N, Petric D, Zgomba, Boase C, Madon, Dahl, Kaiser A (2010) Chemical Control. Mosquitoes and Their Control 2010: 441-475 doi: 10.1007/978-3-540-92874-4

Bisset JA, Marín R, Rodríguez MM, Severson DW, Ricardo Y, French L, Díaz M, Pérez O (2013) Insecticide resistance in two Aedes aegrpti (Diptera: Culicidae) strains from Costa Rica. Journal of Medical Entomology 50(2): 352-361 doi: 10.1603/ME12064

Brazilian Health Minitry, 2012. Dengue Epidemic Report Cases from January to December 2012. Available at: http:// portal.saude.gov.br/portal/saude/area.cfm?id_ area $=1525$. Accessed July 2013

Cabral MMO, Alencar JA, Guimarães AE, Kato MJ (2009) Larvicidal activity of grandisin against Aedes aegypti. Journal of the American Mosquito Control Association 25(1):103-105 doi: 10.2987/08-5828.1

Calderon AI, Romero LI, Ortega-Barria E, Brun R, Correa A, Mireya D, Mahabir P (2006) Evaluation of larvicidal and in vitro antiparasitic activities of plants in a biodiversity plot in the Altos de Campana National Park, Panama. Pharmaceutical Biology 44(7):487-498 doi: 10.1080/13880200600878361

Cantrell CL, Dayan, FE, Duke SO (2012) Natural Products as Sources for New Pesticides. Journal of Natural Products 75 (6):1231-1242 doi: 10.1021/np300024u

Chaithong U, Choochote W, Kamsuk K, Jitpakdi A, Tippawangkosol P, Chaiyasit D, Champakaew D, Tuetun B, Pitasawat B (2006) Larvicidal effect of pepper plants on Aedes aegypti (L.) (Diptera: Culicidae). Journal of the Society for Vector Ecology 31(1):138-144 doi: 10.3376/1081-1710(2006)31[138:LEOPPO]2.0.CO;2

Chaiyasit D, Choochote W, Rattanachanpichai E, Chaithong U, Chaiwong P, Jitpakdi A, Tippawangkosol P, Riyong D, Pitasa B (2006) Essential oils as potential adulticides against two populations of Aedes aegypti, the laboratory and natural field strains, in Chiang Mai province, northern Thailand. Parasitology Research 99: 715-721 doi: 10.1007/s00436-006-0232-x

Chansang U, Zahiri NS, Bansiddhi J, Boonruad T, Thongsrirak P, Mulla MS (2005) Mosquito larvicidal activity of aqueous extracts of long pepper (Piper retrofractum Vahl) from Thailand. Journal of Vector Ecology 30 (2): 195-200 (PMID:16599152) 
Chantraine JM, Laurent D, Ballibian C, Saavedra G, Ibañez R, Vilaseca LA (1998) Insecticidal activity of essential oils on Aedes aegypti larvae Phytotherapy Research 12: 350-354 doi: 10.1002/(SICI)10991573(199808)12:5<350::AID-PTR311>3.0.CO;2-7

Chaveerach A, Mokkamul P, Tanee T (2006) Ethnobotany of the Genus Piper in Thailand. Ethnobotany Research \& Applications 4: 223-232 doi: hdl.handle.net/10125/297

Choochote W, chaithong U, Kamsuk K, Rattanachanpichai E, Jitpakdi A, Tippawangkosol P, Tuetun B, Pitasawat B (2006) Adulticidal activity against Stegomyia aegypti (Diptera: Culicidae) of three Piper spp. Revista do Instituto de Medicina Tropical de São Paulo 48 (1): 33-37 doi: 10.1590/S0036-46652006000100007

Costa JGM, Santos PF, Brito SA, Rogrigues FFG, Coutinho HDM, Botelho MA, Lima SG (2010) Composição Química e Toxicidade de Óleos Essenciais de Espécies de Piper Frente a Larvas de Aedes aegypti L. (Diptera: Culicidae. Latin American Journal of Pharmacy 29 (3): 463467 doi: hdl.handle.net/10915/7934

Cruz S M, Caceres A, Alvarez L, Morales J, Apel M A, Henriques A T, Salamanca E, Gimenez A, Vasquez Y, Gupta MP (2011) Chemical composition of essential oils of Piper jacquemontianum and Piper variabile from Guatemala and bioactivity of the dichloromethane and methanol extracts. Revista Brasileira de Farmacognosia 21(4): 587-593 doi: 10.1590/S0102-695X2011005000110

Cunico MM, Carvalho JLS, Auer CG (2005) Gênero Ottonia: uma revisão das principais características botânicas, fitoquímicas e biológicas. Revista Brasileira de Plantas Medicinais 7:17-21 http://www.sbpmed.org.br/ download/issn_05_2/artigo_4_v7_n2.pdf

Da Silva JK, Andrade EH, Kato MJ, Carreira LM, Guimarães EF, Maia JG (2011) Antioxidant capacity and larvicidal and antifungal activities of essential oils and extracts from Piper krukoffii. Natural Product Communications 6(9): 1361-1366 PMID: 21941916

Das SK (2013) Mode of action of pesticides and the novel trends - A critical review. International Research Journal of Agricultural Science and soil Science 3(11): 393-401 doi: 10.14303/irjas.2013.118

Dayan FE, Cantrell CL, Duke SO (2009) Natural products in crop protection. Bioorganic \& Medicinal Chemistry 17: 4022-4034 doi: 10.1016/j.bmc.2009.01.046

Dick OB, San Martın JL, Montoya RH, del Diego J, Zambrano B, Dayan, GH (2012) Review: The History of Dengue Outbreaks in the Americas. American Journal of Tropical Medicine and Hygiene 87(4): 584-593 doi: 10.4269/ajtmh.2012.11-0770

Duke SO (1990) Natural pesticides from plants In: Janick $\mathrm{J}$ and Simon JE (eds.), Advances in new crops, Timber Press, Portland, OR pp. 511-517.
Duke SO, Cantrell CL, Meepagala KM, Wedge DE, Tabanca N, Schrader, KK (2010) Natural Toxins for Use in Pest Management. Toxins (2): 1943-1962 doi: $10.3390 /$ toxins 2081943

Ee GCL, Lim SK, Lim CM, Dzulkefly K (2008) Alkaloids and carboxylic acids from Piper nigrum Asian Journal of Chemistry 20(8):5931-5940 http://www. asianjournalofchemistry.co.in/User/ViewFreeArticle. aspx?ArticleID=20_8_19

El-Kattan AF, Asbill CS, Kim, N.; Michniak, B. B (2001) The effects of terpene enhancers on the percutaneous permeation of drugs with different lipophilicities. International Journal of Pharmaceutics 215: 229-240 doi: 10.1016/S0378-5173(00)00699-2

Epelboin L, Boulle' C, Ouar-Epelboin S, Hanf M, Dussart P, et al. (2013) Discriminating Malaria from Dengue Fever in Endemic Areas: Clinical and Biological Criteria, Prognostic Score and Utility of the C-Reactive Protein: A Retrospective Matched-Pair Study in French Guiana. PLoS Neglected Tropical Diseases 7(9): e2420 doi: 10.1371/ journal.pntd.0002420

Garcez W S, Garcez F R, Silva LMGE, Sarmento UC (2013) Naturally occurring plant compounds with larvicidal activity against Aedes aegypti. Revista Virtual de Quimica 5(3): 363-393 ICID: 1067481

Ghosh A, Chowdhury N, Chandra G (2012) Plant extracts as potential mosquito larvicides. Indian Journal of Medical Research 135(5):581-598 PMCID: PMC3401688

Gould EA, Solomon T, 2008. Pathogenic flaviviruses. Lancet 371: 500-509 doi: 10.1016/S01406736(08)60238-X

Grzybowski A, Tiboni M, da Silva MAN, Chitolina RF, Passos M, Fontana JD (2012) The combined action of phytolarvicides for the control of dengue fever vector, Aedes aegypti. Revista Brasileira de Farmacognosia 22(3): 549557 doi: 10.1590/S0102-695X2012005000026

Guy B, Saville M, Lang J (2010) Development of Sanofi Pasteur tetravalent dengue vaccine. Human Vacines 6(9): 669-705 PMID:20861669

Guimarães EF, Monteiro, D (2006) Piperaceae na Reserva Biológica de Poço das Antas, Silva Jardim, Rio de Janeiro, Brasil Rodriguésia (57) 567-587 http://rodriguesia.jbrj. gov.br/rodrig57_3/12Piperaceae.pdf

Guimarães EF, Silva MC (2009) Uma nova espécie e novos nomes em Piper seção Ottonia (Piperaceae) para o Sudeste do Brasil. Hoebnea 36: 431-435 doi: 10.1590/ S2236-89062009000300004

Heil M, Bostock RM (2002) Induced Systemic Resistance (ISR) Against Pathogens in the Context of Induced Plant Defences. Annals of Botany 89: 503-512 doi: 10.1093/aob/mcf076 
Hidayatulfathi O, Sallehuddin S, Ibrahim J (2004) Adulticidal activity of some Malaysian plant extracts against Aedes aegypti Linnaeus. Tropical biomedicine 21(2): 61-67 PMID: 16493400

Intirach J, Junkum A, Tuetun B, Choochote W, Chaithong U, Jitpakdi A, Riyong D, Champakaew D, Pitasawat B (2012) Chemical Constituents and Combined Larvicidal Effects of Selected Essential Oils against Anopheles cracens (Diptera: Culicidae). Psyche 2012: 1-12 doi: 10.1155/2012/591616

Lara Júnior CR, Oliveira GL, Mota BCF, Moreira DL, Kaplan MAC (2012) Antimicrobial activity of essential oil of Piper aduncum L. (Piperaceae). Journal of Medicinal Plants Research 6(21): 3800-3805 doi: 10.5897/ JMPR12.738

Lavor PL, Santiago GMP, Gois RW, de Sousa LM, Bezerra GP, Romero NR, Arriaga AMC, Lemos TLG, Alves PB, Gomes PCS (2012) Larvicidal activity against Aedes aegrpti of essential oils from northeast Brazil. Natural Product Communications 7(10):1391-1392 PMID: 23157019

Lee HS (2005) Pesticidal constituents derived from Piperaceae fruits. Agricultural Chemistry and Biotechnology 48(2): 65-74 http://agris.fao.org/agris-search/search. do?recordID=KR2006013080

Leite ACCF, Kato MJ, Soares ROA, Guimaraes AE, Santos-Mallet JR, Cabral MMO (2012) Grandisin caused morphological changes larval and toxicity on Aedes aegrpti. Revista Brasileira de Farmacognosia 22(3): 517521 doi: 10.1590/S0102-695X2012005000016

Leyva M, Marquetti MC, Tacoronte JE, Scull R, Tiomno O, Mesa A, Montada D (2009) Actividad larvicida de aceites esenciales de plantas contra Aedes aegrpti (L.) (Diptera: Culicidae). Revista Biomedica 20: 5-13 http:// www.revbiomed.uady.mx/pdf/rb092012.pdf

Lima EP, Paiva MHS, Araújo AP, Silva EVG et al (2011) Insecticide resistance in Aedes aegypti populations from Ceará, Brazil. Parasites \& Vectors 4(5): 1-12 doi: 10.1186/1756-3305-4-5

Lichtenstein EP, Liang TT, Schulz KR, Schnoes HK, Carter GT (1974) Insecticidal and synergistic components isolated from dill plants. Journal of Agricultural and Food Chemistry 22: 658-664 doi: 10.1021/jf60194a037

Mann RS, Kaufman PE (2012) Natural Product Pesticides: Their Development, Delivery and Use Against Insect Vectors. Mini-reviews in Organic Chemistry 9: 185-202 doi: 10.2174/157019312800604733

Marques AM, Barreto AL, Batista E, Curvelo JAR, Velozo LSM, Moreira DL, Guimarães EF, Soares RMA, Kaplan MAC (2010) Chemistry and Biological Activity of Oils from Piper claussenianum (Piperaceae). Natural Product Communications 5(11): 1837-1840 PMID: 21213995
Marques AM, Paiva RA, Fonseca LM, Capella MAM, Guimarães EF, Kaplan MAC (2013) Preliminary Anticancer Potency Evaluation and Phytochemical investigation of Methanol Extract of Piper claussenianum (Miq.) C.DC. Journal of Applied Pharmacentical Science 3(02): 13-18 doi: 10.7324/JAPS.2013.30203

Massebo F, Tadesse M, Bekele T, Balkew M, Gebre-Michael T (2009) Evaluation on larvicidal effects of essential oils of some local plants against Anopheles arabiensis Patton and Aedes aegrpti Linnaeus (Diptera, Culicidae) in Ethiopia. African Journal of Biotechnology 8:(17) 4183-4188 doi: 10.5897/AJB2009.000-9405

Mongelli E, Desmarchelier C, Coussio J, Ciccia G (1995) Actividad antimicrobiana e interacción con el adn de plantas medicinales de la Amazonia. Revista Argentina de Microbiologia 27(4): 199-203 PMID:8850132

Mongelli E, Coussio J, Ciccia G (2002) Investigation of the larvicidal activity of Pothomorphe peltata and isolation of the active constituent. Phytotherapy Research 16 (1): S71-S72 http://www.sbpmed.org.br/download/ issn_06_4/8esp_205_211.pdf

Moraes J, Nascimento C, Lopes POMV (2011) Schistosoma mansoni: In Vitro Schistosomicidal Activity of Piplartine. Experimental Parasitology 127: 357-364 doi: 10.1016/j. exppara.2012.07.004

Morais SM, Facundo VA, Bertini LM, Cavalcanti ESB, Ferreira SA, Brito ES, Souza Neto MA (2007) Chemical composition and larvicidal activity of essential oils from Piper species. Biochemical Systematics and Ecology 35: 670-675 doi: 10.1016/j.bse.2007.05.002

Murray NEA, Quam MB, Wilder-Smith A (2013) Epidemiology of dengue: past, present and future prospects. Clinical Epidemiology 5: 299-309 doi: 10.2147/ CLEP.S34440

Murthy JM, Rani PU (2009) Biological activity of certain botanical extracts as larvicides against the yellow fewer mosquito, Aedes aegypti L. Journal of Biopesticides 2(1):72-76 http://agris.fao.org/agris-search/search. do? recordID $=\mathrm{IN} 2011000029$

Myers N, Mittermeier RA, Mittermeier CG, Fonseca GAB, Kent J (2000) Biodiversity Hotspots for Conservation Priorities. Nature 403: 853-858 doi: 10.1038/35002501

Nagori K, Singh MK, Kumar T, Dewangan D, Badwaik H, Tripathi DK (2011) Piper betle L.: A review on its ethnobotany, phytochemistry, pharmacological profile and profiling by new hyphenated technique DARTMS (Direct Analysis in Real Time Mass Spectrometry). Journal of Pharmacy Research 4(9): 2991-2997 ICID: 989093

Nascimento JC, David JM, Barbosa LC, de Paula VF, Demuner AJ, David JP, Conserva LM, Ferreira JC, Guimarães EF (2013) Larvicidal activities and chemical 
composition of essential oils from Piper klotzscbianum (Kunth) C. DC. (Piperaceae) Pest management science 69(11): 1267-1271 doi: 10.1002/ps.3495

Nawaz R, Rathor HR, Bilal H, Hassan S, Khan IA (2011) Adulticidal Activity of Olea vera, Linum usitatissimum and Piper nigera against Anopheles stephensi and Aedes aegypti under Laboratory Conditions. Iranian Journal of Arthropod-borne Diseases 5(2): 2-9 http://jad.tums.ac.ir/ index.php/jad/article/view/99/84

Norashiqin M, Hidayatulfathi O, Sallehudin S (2011) The effect of Piper aduncum Linn. (Family: Piperaceae) essential oil as aerosol spray against Aedes aegypti (L.) and Aedes albopictus Skuse. Tropical biomedicine 28(2): 249-258 PMID:22041743

PAHO. Number of reported cases of dengue and dengue hemorrhagic fever (DHF), Region of the Americas (by country and subregion). Washington, DC, Pan American Health Organization, 2008. Available at: http://www.paho.org/english/ad/ $\mathrm{dpc} / \mathrm{cd} /$ dengue.htm. Accessed October 2013

Pan American Health Organization (PAHO). Number of reported cases of dengue and dengue hemorrhagic fever (DHF), Region of the Americas (by country and subregion) from 1995 through 2010. Accessed October 2013.

Parmar VS, Jain SC, Bisht KS, Jain R, Taneja P, Jha A, Tyagi OD, Prasad AK, Wengel J (1997) Phytochemistry of Genus Piper. Phytochemistry 46(4): 597-673 doi: 10.1016/ S0031-9422(97)00328-2

Pinto ACS, Nogueira KL, Chaves FCM, Silva LVS, Tadei WP, Pohlit AM (2012) Adulticidal Activity of Dillapiol and Semi-synthetic Derivatives of Dillapiol against Aedes aegypti (L.) (Culicidae). Journal of Mosquito Research 2(1): 1-7 doi: 10.5376/jmr.2012.01.0001

Pinto ACS, Pessoa C, Lotufo LVC, Moraes MOM, Moraes ME, Cavalcanti BC, Nunomura SN, Pohlit AM (2006) In vitro cytotoxicity of Pothomorphe peltata (L.) Miquel (Piperaceae), isolated 4-nerolidylcatechol and its semisythetic diacetyl derivative. Revista Brasileira de Plantas Medicinais 8: 205-211 http://www.sbpmed.org.br/ download/issn_06_4/8esp_205_211.pdf

Platt KB, Linthicum L, Myint KSA, Innis BL, Lerdthusnee K, Vaughn DW (1997) Impact of dengue virus infection on feeding behavior of Aedes aegypti. American Journal of Tropical Medicine and Hygiene 57(2): 119-125 PMID: 9288801

Pohlit AM, Quignard ELJ, Massayoshi S, Nunomura et al (2004) Screening of plants found in the State of Amazonas, Brazil for larvicidal activity against Aedes aegypti larvae. Acta Amazônica 34(1): 97 - 105 doi: 10.1590/S0044-59672004000100012

Rafael MS, Hereira-Rojas WJ, Roper JJ, Nunomura SM, Tadei WP (2008) Potential control of Aedes aegypti (Diptera: Culicidae) with Piper aduncum L. (Piperaceae) extracts demonstrated by chromosomal biomarkers and toxic effects on interphase nuclei. Genetics and molecular research 7(3): $772-781$ PMID: 18767246

Rahman A (2012) Studies in Natural Products Chemistry, 1st Edition. vol 37. University of Karachi, Pakistan, pp544.

Raimundo JM, Trindade APF, Velozo LSM, Kaplan MAC, Takashi-Sudo R, Zapata-Sudo G (2009) The Lignan Eudesmin Extracted from Piper truncatum Induced Vascular Relaxation via Activation of Endothelial Histamine H, Receptors. European Journal of Pharmacology 606: 150-154 doi: 10.1016/j.ejphar.2009.01.038

Ramasamy R, Surendran SN, Jude PJ, Dharshini S, Vinobaba M (2011) Larval Development of Aedes aegypti and Aedes albopictus in Peri-Urban Brackish Water and Its Implications for Transmission of Arboviral Diseases. PLoS Neglected Tropical Diseasis 5(11): e1369 doi: 10.1371/journal.pntd.0001369

Rebelo RA, Santos TG, Dalmarco EM, Guedes A, Gasper AL, Steidel M, Nunes RK (2012) Composição Química e Avaliação da Atividade Antimicrobiana do Óleo Essencial das Folhas de Piper malacophyllum (C. Presl.) C. DC. Química Nova 35: 477-481 doi: 10.1590/S010040422012000300007

Rimando A, Duke SO (2006) Natural Products for Pest Management. Chapter 01. ACS Symposium Series; American Chemical Society: Washington, DC, 2006. doi: 10.1021/bk-2006-0927.ch001

Sarita K, Radhika W, Naim W (2010) Larvicidal potential of ethanolic extracts of dried fruits of three species of peppercorns against different instars of an indian strain of dengue fever mosquito, Aedes aegypti L. (Diptera: Culicidae). Parasitology research 107(4): 901-907 doi: 10.1007/s00436-010-1948-1

Sarita K, Radhika W, Naim W (2011) Relative Larvicidal Efficacy of Three Species of Peppercorns against Dengue Fever Mosquito, Aedes aegypti L. Journal of the Entomological Research Society 13(2): 27-36 http://www. entomol.org/journal/index.php?journal

Scott IM, Jensen HR, Philogène BJR, Arnason JT (2008) A review of Piper spp. (Piperaceae) phytochemistry, insecticidal activity and mode of action. Phytochemical reviews 7(1): 65-75 doi: 10.1007/s11101-006-9058-5

Siddiqui BS, Gulzar T, Begum S, Rasheed M, Sattar FA, Afshan F (2003) Two New Insecticidal Amides and a New Alcoholic Amide from Piper nigrum L. Helvetica Chimica Acta 86: 2760-2767 doi: 10.1002/ hlca.200390225

Siddiqui BS, Gulzar T, Mahmood A, Begum S, Khan B, Afshan F (2004) New insecticidal amides from petroleum ether extract of dried Piper nigrum $\mathrm{L}$. whole fruits. Chemical \& pharmacentical bulletin 52: 1349-1352 PMID: 15516761 
Siddiqui BS, Gulzar T, Begum S, Afshan F, Sattar FA (2005) Insecticidal amides from fruits of Piper nigrum Linn. Natural Product Research 19(2):143-150 doi: $10.1080 / 14786410410001704750$

Silva RZ, Yunes RAM,DeSouza MM (2010) Antinociceptive Properties of Conocarpan and Orientin Obtained from Piper solmsianum C.DC. Var. solmsianum (Piperaceae). Journal of Natural Medicines 64(4): 402-408 doi: 10.1007/ s11418-010-0421-x

Simas NK, Lima EC, Conceição SR, Kuster RM, Oliveira Filho AM (2004) Produtos naturais para o controle da transmissão da dengue - atividade larvicida de Myroxylon balsamum (óleo vermelho) e de terpenóides e fenilpropanóides. Quimica Nova 27(1): 46-49 doi: 10.1590/S0100-40422004000100009

Simas NK, Lima EC, Kuster RM, Lage CLS, de Oliveira FAM (2007) Potential use of Piper nigrum ethanol extract against pyrethroid-resistant Aedes aegypti larvae. Revista da Sociedade Brasileira de Medicina Tropical 40(4): 405-407 doi: 10.1590/S0037-86822007000400006

Simmons M, Teneza-Mora N, Putnak R (2012) Advances in the development of vaccines for dengue fever. Vacine: Development and Therapy 2012(2): 1-14 http://dx.doi. org/10.2147/VDT.S22577

Solis PN, Olmedo D, Nakamura N, Calderon AI, Hattori M, Gupta MP (2005) A new larvicidal lignan from Piper fimbriulatum. Pharmacentical Biology 43(4):378-381 doi: 10.1080/13880200590951865

Tawatsin A, Asavadachanukorn P, Thavara U, Wongsinkongman P, Bansidhi J, Boonruad T, Chavalittumrong P, Soonthornchareonnon N, Komalamisra N, Mulla MS (2006) Repellency of essential oils extracted from plants in Thailand against four mosquito vectors (Diptera:Culicidae) and oviposition deterrent effects against Aedes aegypti (Diptera:Culicidae). Southeast Asian Journal of Tropical Medicine and Public Health 37(5): 915-931 PMID: 17333734

Tennyson S, Arivoli S, Raveen R, Bobby M, Dhinamala K (2012) Larvicidal activity of Areca catechu, Nicotiana tabacum and Piper betle leaf extracts against the dengue vector Aedes aegypti (L.) (Diptera: Culicidae). International Journal of Research in Biological Sciences 2(4):157-160 http://urpjournals.com/ tocjnls/27_12v2i4_5.pdf

ThisyakornU,Thisyakorn, C(2013)Latestdevelopments and future directions in dengue vaccines. Therapeutic Advances in Vaccines 2013: 1-7 doi: 10.1177/2051013613507862

Vontas J, Kioulos E, Pavlidi N, Ranson H (2012) Insecticide resistance in the major dengue vectors Aedes albopictus and Aedes aegypti. Pesticide Biochemistry and Physiology 104(2): 126-131 doi: 10.1016/j.pestbp.2012.05.008
World Health Organization, 2009. Dengue guidelines for diagnosis, treatment, prevention and control. Available at: http://www.who.int/tdr/publications/documents/ dengue-diagnosis.pdf Accessed August 2013.

World Health Organization, 2012. Global strategy for dengue prevention and control 20122020.Available at: http://apps.who.int/iris/ bitstream/10665/75303/1/9789241504034_eng.pdf. Accessed October 2013.

Yang YC, Lee SG, Lee HK, Kim MK, Lee SH, Lee HS (2002) A piperidine amide extracted from Piper longum L. fruit shows activity against Aedes aegppti mosquito larvae. Journal of agricultural and food chemistry 50(13): 3765-3667 doi: 10.1021/jf011708f

Young-Cheol Y, Sang-Guei L, Hee-Kwon L, Moo-Key K, Sang-Hyun L, Hoi-Seon, L (2002) A piperidine amide extracted from Piper longum $\mathrm{L}$. fruit shows activity against Aedes aegypti mosquito larvae. Journal of agricultural and food chemistry 50(13): 3765-3767 doi: 10.1021/jf011708f 
Metabolitos activos del género Piper contra Aedes aegypti: fuentes alternativas naturales para el control de vectores de dengue

Resumen. El mosquito, Aedes aegypti, es el principal vector del dengue y de la fiebre hemorrágica. El mosquito está diseminado en regiones tropicales y subtropicales. $\mathrm{La}$ prevalencia del dengue lo hace una de las enfermedades virales, transmitidas por mosquitos, más importantes en el mundo, ocurriendo anualmente en más de 100 países endémicos. Dado que la sangre es esencial para su ciclo de desarrollo, la especie Aedes mantiene una estrecha relación con los seres humanos y sus viviendas. La estrategia más ampliamente adoptada para disminuir la incidencia de estas enfermedades es el control de las larvas de los mosquitos. La aparición de mosquitos resistentes a los insecticidas ha amplificado el interés en la búsqueda de productos naturales, eficaces contra Aedes aegypti adultos y larvas. Los compuestos derivados de plantas han jugado un papel importante en el descubrimiento de nuevas entidades activas para el control del vector; estos son más seguros y menos tóxicos para los seres humanos en comparación con los insecticidas convencionales. Esta reseña evalúa matrices vegetales de origen natural y compuestos puros de especies Piper, que han demostrado ser activos contra Aedes aegypti.

Palabras clave: dengue; Aedes aegypti; Piper; Piperaceae; metabolitos larvicidas; enfermedades tropicales.
Metabólitos secundarios do gênero Piper contra Aedes aegypti: fontes naturais alternativas para o controle do vector da dengue

Resumo. O mosquito Aedes aegypti é o principal vetor dos vírus responsáveis pela dengue e pelas febres hemorrágicas de dengue. O mosquito está generalizado em todas as regiões tropicais e sub-tropicais; a sua prevalência torna a dengue uma das doenças virais mais importantes transmitidas por mosquitos no mundo que ocorrem anualmente em mais de 100 países endémicos. Como o sangue é essencial para o seu ciclo de desenvolvimento, a espécie Aedes mantém uma estreita associação com os seres humanos e suas habitações. Apropriadamente, a estratégia mais adotada para diminuir a incidência dessas doenças é o controle da população de larvas de mosquito. O surgimento de mosquitos resistentes aos inseticidas tem ampliado o interesse em encontrar produtos naturais eficazes contra Aedes aegypti adultos, bem como larvas. Compostos derivados de plantas, têm desempenhado um papel importante na descoberta de novas entidades ativas para gestão de vetores em que são mais seguros e possuem baixa toxicidade para os seres humanos, em comparação com os insecticidas convencionais. Esta avaliação avalia a matriz de plantas que ocorrem naturalmente e compostos puros das espécies de Piper, que têm se mostrado ativa contra Aedes aegypti.

Palavras-chave: dengue; Aedes aegypti; Piper, Piperaceae; metabólitos larvicidas; doenças tropicais.. 